\title{
Resim Kompozisyonları ve Üsluplarının Sahne Tasarımında Kullanım Yöntemleri
}

\author{
Usage Methods of Painting Compositions and Styles in Stage Design \\ Cem Çevikayak, Sahne Sanatları Bölümü, Dokuz Eylül Üniversitesi
}

\begin{abstract}
Özet
Sahne tasarımı alanında resim kompozisyonlarının iki boyutlu, statik yapısının üç boyutlu, hareketli, canlı bir performansla tekrar biçimlendirilmesi görsel anlamda farklı dramatik yorumlamalara kapı açmaktadır. Çünkü tiyatro sahnesinde, dramatik anlatıya hizmet edebilecek ve sergilenen eseri görselleştirecek birçok yüzey, yöntem, katman mevcuttur. Dolayısıyla bu tasarım yaklaşımı çeşitlemeleri hem referans alınan resim kompozisyonuna yeni bakıș açıları kazandırabilmekte hem de seyircinin aktif olarak duyularına hitap ederek zaman ve hareket boyutunda durağanlığı kırmaktadır. Çalışmada, 21. yüzyılda sahnelenmiş tiyatro oyunları, dans gösterileri ve opera temsillerine odaklanılarak, bu temsillerin sahne tasarımlarındaki belirgin resim kompozisyonu referansları derlenmiş ve bu eserlerdeki tasarım yaklașımları incelenmiștir. Seçilen ve sıralanan yapımların sahne tasarımı yaklașımları gerek temsillerin çeşitli fotoğraflarından gerek eserle ilgili yazılan eleştiri ve verilen röportajlardan edinilen bilgilerle ele alınmıştır. Farklı dönemlerden resim kompozisyonlarının tiyatro sahnesinde yeniden canlandığ örnekler, sahne tasarımlarındaki kullanım farklılıklarına göre sıralanmıştır. İki boyutlu bir resim kompozisyonunun, dramatik bir anlatıyla buluşturularak üç boyutlu bir mekân hacmine yerleştirilmesi ve devinimsel anlatıma görsel olarak katkısı üzerinde durulmuştur.
\end{abstract}

Anahtar Kelimeler: Resim, tiyatro, sahne tasarımı, kompozisyon, dramatizasyon.

Akademik disipin(ler)/alan(lar): Resim, sahne sanatları, sahne tasarımı.

\begin{abstract}
In the field of stage design, reshaping the two-dimensional, static structure of the painting compositions with a three-dimensional, moving, live performance opens the door to different dramatic interpretations in the visual sense. Because there are many surfaces, methods and layers that can serve the dramatic narrative and visualize the exhibited work on the theater stage. Therefore, these variations of design approaches can both bring new perspectives to the reference painting composition and break the stagnation in time and movement by actively appealing to the senses of the audience. In the study, by focusing on the theater plays, dance performances and opera performances staged in the 21st century, the distinctive picture composition references in the stage designs of these performances were compiled and the design approaches in these works were examined. The stage design approaches of the selected and listed productions are discussed with the information obtained from the various photographs of the performances, the criticism written about the work and the interviews given. The examples in which painting compositions from different periods are revived on the theater stage are listed according to the differences in use in stage designs. The placement of a two-dimensional painting composition in a threedimensional space volume by combining it with a dramatic narrative and its visual contribution to the kinetic expression were emphasized.
\end{abstract}

Keywords: Painting, theatre, stage design, composition, dramatisaiton.

Academical disciplines/fields: Painting, performance arts, stage design.

- Sorumlu Yazar: Cem Çevikayak, Sahne Sanatları Bölümü, Güzel Sanatlar Enstitüsü, Dokuz Eylül Üniversitesi.

- $\quad$ Adres: Merkez Mah. Kars Cad. No:4, Dr: 101, Posof, Ardahan.

- e-posta: cemcev@gmail.com

- ORCID: 0000-0002-0128-002X

- Çevrimiçi yayın tarihi: 21.09 .2021

- doi: $10.17484 /$ yedi.901964 


\section{Giriş}

Resim, kendisine bakan kişiye sunulan görsel ve duygusal bir gerçekliğin ifadesidir. Ressam, lekeler, çizgiler ve renklerle bireysel yeteneğini kullanarak hikâyesini veya fikirlerini tek karede ifade etmektedir. Bunun için kullandığı en temel malzemeler boya, firça ve tuvaldir. Zamanın en kayda değer görsel malzemeleri haline gelmiş resimler, aynı zamanda içinde bulunulan çağın estetik algılarını ve beğenilerini ifade eden en önemli pencerelerdir. İki boyutlu düzlemde perspektif ve anatomi kurallarına uygun olarak zamanı resmetme işlevi gören resimler bu anlamda, yaşamdan görkemli kesitler sunan biricik sahnelerdir.

Resim alanından eserler, bulunduğu dönemin bakış açlarına, gerçeğe olan yaklaşımlarına ve estetik anlayışlarına dair ipuçları ortaya koyabilmektedir. Farklı zaman dilimlerine pencereler açarak, ışık/gölge, perspektif, renk oyunları ile izleyiciyle görsel anlamda iletişime geçmekte ve farklı duygular uyandırmaktadır. Bu anlamda sanat tarihindeki akışta belirli dönemlerin önemli estetik unsurlarını ortaya koyan ve uzunca süre yaşatan eserler, daha çok resim alanında örneklendirilmektedir. Dolayısıyla tuval üzerinde sadece ressamın tasvir ettiği konuya değil, yapıldığı döneme dair de bilgiler içerir. Aynı zamanda izleyicinin resimle olan iletişim süresi ve bağı da tamamen subjektiftir.

Resim sanatına, sahne sanatları alanından bir pencere açacak olursak, sahne tasarımı sürecinde, dramaturji ve performans yaklaşımına göre atmosfer oluşturmak ve bunu sahneleme mekânının mimari yapısına göre kurmak öngörülen bir yöntemdir. Bu süreç içerisinde tiyatro oyununun çıkış noktasının bir resim olması, görselliği dolayısıyla sahne tasarımını ön plana çıkarmaktadır. Bu türden bir tasarım yaklaşımında sahne üzerindeki hareketli veya hareketsiz her etmen, amaçlanan büyük resmi oluşturmaya hizmet etmekte ve performe edilen dramatik anlatı ile tasarım referansı alınan resim kompozisyonu arasında içerik ve görsel katmanlarında bağ kurmaktadır. Bu amaç doğrultusunda referans alınan resim, bütünüyle sahneye taşınabilir, içindeki mekânsal ve figüratif etmenler birbirinden ayrılarak yansıtılabilir, oyuncuların bizzat resimdeki sahneyi canlandırmaları sağlanabilir veya resmin renklerinin sahne fonunda oyuna atmosfer yaratması amacıyla kullanılması yöntemi uygulanabilir. Farklı birer biçimsel yöntem olarak tercih edilen bu yollar, seyirci ve sahne eseri arasındaki iletişim bağına yeni bir boyut kazandırmaktadır. Bu türden bir sahne tasarımı uygulamasında kaynak alınan iki boyutlu resim kompozisyonu birçok farklı yöntem ile tiyatro sahnesinde üç boyutlu olarak yaşatılabilmektedir. Böylece tiyatronun seyir tarafinda bir sanat eserinin farklı bir yorumla tekrar gözlemlenebilmesi sağlanmaktadır.

\section{Biyografik Sahne Eserlerinde Tasarım Öğesi Olarak Resim}

Resim sanatının ve sahne tasarımının buluştuğu örnekler, eser üzerinden ve sanatçı üzerinden olmak üzere ikiye ayrılabilir. Mevcut eserlerin sahne üzerinde dramatik aksiyona hizmetine yönelik dönüşümünde, resim kompozisyonu tasarım parçası olarak deformasyona uğratılabilmekte ve kolaj malzemesi olarak kullanılabilmektedir. Özellikle sahne üzerinde canlandırılan hikâye, gerçek hayattan bir ressamın hayatı ise eserlerinin de onunla beraber tekrar yaşatılması, onun yaşamıla bütünleştirilmesi biyografik tiyatro oyunlarında çokça kullanılan bir yöntemdir. Biyografik sahne eserlerinde, modern ressamların hayatlarından belirli kesitleri görselleştirme konusunda referans alınan resimler, aynı zamanda bu sanatçıların tercih ettikleri görsel ifade biçimlerindeki gelişim ve değişimleri de kronolojik olarak seyirciye sunmaktadır. Tiyatro oyunlarında birer dramatik karakter olarak kaleme alınmış ve canlandırılmış ressamlar arasında Vincent Van Gogh, Frida Kahlo, Francisco Goya, Pablo Picasso, George Seurat gibi önemli isimler sayılabilir. Biyografik oyun temsillerinden seçilen bu örneklerde, sahne tasarımlarındaki resimsel alıntılar üzerinden yaşamı anlatılan modern ressamların eserleri, kurgusal sahne mekânı ve hareket rejisi ile bütünleştirilmiştir.

Biyografik oyunlarda sanatçı figürlerinin yaygın bir biçimde kullanıldığı ve özellikle geleneksel/gerçekçi üslupta benzer mitsel algılarla biçimlendiği dikkati çekmektedir. Sanatçı biyografilerini kullanan oyunları edebiyat kuramındakine benzer bir biçimde künstlerdrama ${ }^{1}$ olarak adlandırabiliriz. Büyük adam geleneği romantizmin derin otonom benlik tasarımının bir sonucudur. Romantizmin bireysellik nosyonu sanatçıyı içsel bir devrim yaşayan, bilinçli bir şekilde bağımsızlığına ulaşmaya çabalayan bir dahi olarak görmüştür. Romantik sanatçllar da otobiyografik anlatılarında kendilerini idealize imajlar vasıtasıyla stilize etmektedirler. Yazar tarafında ise sanatçının yaşam-sanat arasında kurduğu yoğun ilişki, onu biyografik özne olarak cazip kılmaktadır. Biyografik dram yazarları da romantizmin sunduğu şiirsellik ile tarihsel gerçekliğin ötesine geçerek, öznenin öyküsünün nezdinde hayatın asıl gerçeğini bulma amacına

\footnotetext{
1 Sanatçllarla ilgili Alman dramaları için kullanılan terimdir. Hem drama hem de tiyatronun tarihi ile ilgili olan 'sahnedeki sanatçı' konusu üzerine oluşturulmuştur.
} 
yönelmektedir. Bu gerçek, sanatçı-öznenin kişisel mitinde kendini gösterecektir. Kişisel mit sadece yaşantıda değil, hatta ondan da fazla sanat eserlerinde ortaya çıkacaktır. Böylece öngörülen yaşam-sanat bağı, sanat eserlerinin de tiyatro oyununa çeşitli düzeylerde dâhil olmasını ve sanatçının gerçek yaşantısını sürdürdüğü uzam olarak kullanılmasını sağlamaktadır (Ünlü, 2015, s. 219).

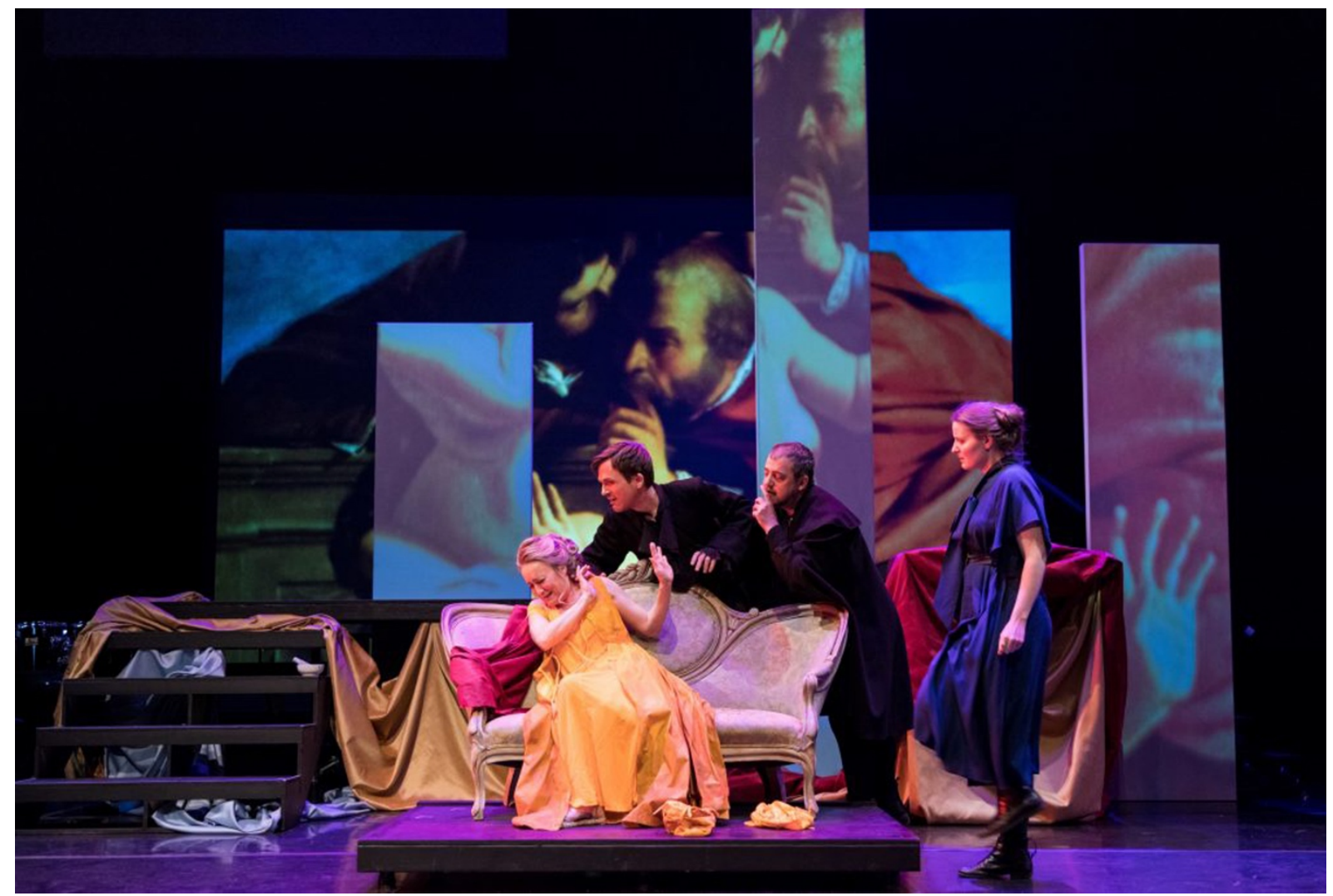

Şekil 1. Artemisia, Left Coast Chamber Ensemble, 2019 (Sachs, 2019).

Klasik resim dönemi sanatçılarının hayatlarından kesitlerin sahnede nasıl resmedildiğine sahne yapımları üzerinden bakacak olursak ilk olarak; 2019 yılında Left Coast Chamber Ensemble'ın sahnelediği 'Artemisia' Operası (bkz. Şekil 1) örnek gösterilebilir. Sahne tasarımı Angrette McCloskey ve kostüm tasarımı ise Maggie Whitaker tarafından gerçekleştirilen yapımda, Barok ressam Artemisia Gentileschi'nin (1593-1656) hayatındaki başarı ve çöküş anlarına odaklanılmıştır. Yer yer sanatçının resim kompozisyonları, sahne arkasında fon olarak tasarım etmenine dönüşmekte ve sahne üzerinde oyuncuların duruşları ile referans alınan figüratif resimlerde görülen duruşlar arasında bağ kurulmaktadır. Gentileschi'nin hayatı sahne üzerinde dramatize edilirken, sahne tasarımında arka plana yerleştirilen parçalı panolar üzerine dijital projeksiyon ile sanatçının yağlı boya tabloları yansıtılmıştır. Bu tasarım yaklaşımı ile hem ressamın sanat hayatından önemli eserler, birden fazla kareyle seyirciyle buluşmuş hem de bu resimlerde görülen sahneler canlı olarak performe edilerek derinlikli dramatik tablolar oluşturulmuştur.

Romantizm akımının önde gelen isimlerinden olan İspanyol ressam ve gravür sanatçısı Francisco Goya'nın (1746-1828) sanat hayatının son dönemlerinden bir kesit sunan 'Goya (Ya Sanat Ya Ölüm)' oyununda ise ressamın en karanlık eserlerini ürettiği yaşlılık dönemleri, Antonio Buero Vallejo'nun kaleme aldığı metnin içerisinde alıntılanan resimleriyle bütünleştirilmiştir. Oyun metninde sahne sahne sembolik olarak kullanılan ve Kara Resimler (1819-1823) olarak anılan Goya'nın bu eserleri, sanatçının kendisi için yaptığı resimlerini birer sahne tasarımı parçasına ve görsel anlatı aracına dönüştürmüştür (Vallejo. 2000). 1998'de Ankara Devlet Tiyatrosu tarafından da sahnelenmiş bu oyunda, metinde belirtilen eserler her bir sahneye uygun olarak, sahne fonuna projeksiyonla yansıtılarak Francisco Goya'nın yaşadığı trajik olaylar aynı dönemlerde ürettiği resimlerle görselleştirilmiştir.

Fovizm akımının en önemli ressamlarından Henri Matisse'in (1869-1954) hayatından bir kesiti sunan Jesse Kornbluth'un yazdığı ve Vantage Theatre tarafından 2018'de sahnelenen 'Color of Light' oyununda da bu 
tarz bir sahne tasarımı yaklaşımı görmekteyiz. Bu temsilde Matisse'in renk teorilerine ${ }^{2}$ dair görseller ve resim estetiği, hikâye akışı içerisinde çizimlerinden parçalar ve desenlerle sahne fonunda senkronize olarak yansıtılmıştır. Modern resim akımlarından sanatçıların hayatları, sahne üzerinde dramatize edilirken yaşamları, sanata dair görüşleri ve üretim aşamaları görsel olarak adeta iç içe geçmektedir. Ressam Egon Schiele'nin (1890-1918) resme yaklaşımını ve yaşamında karşılaştığı zorlukları anlatan Pass the Blutwurst, Bitte (Siyah Pudingi Uzat Lütfen) oyunu da buna bir örnektir. John Kelly tarafından yönetilen ve koreografileri tasarlanan oyun 2012'de New York'ta sahnelenmiştir. Sahne tasarımı için referans alınan Egon Schiele resimleri ise oyunun kimi sahnelerinde arka planda projeksiyonla gösterilmiş, kimi sahnelerde fiziksel olarak tuvallerle ön plana getirilmiş ya da sahnenin merkezinde oyuncular tarafından üç boyutlu hale getirilerek canlandırılmıştır.

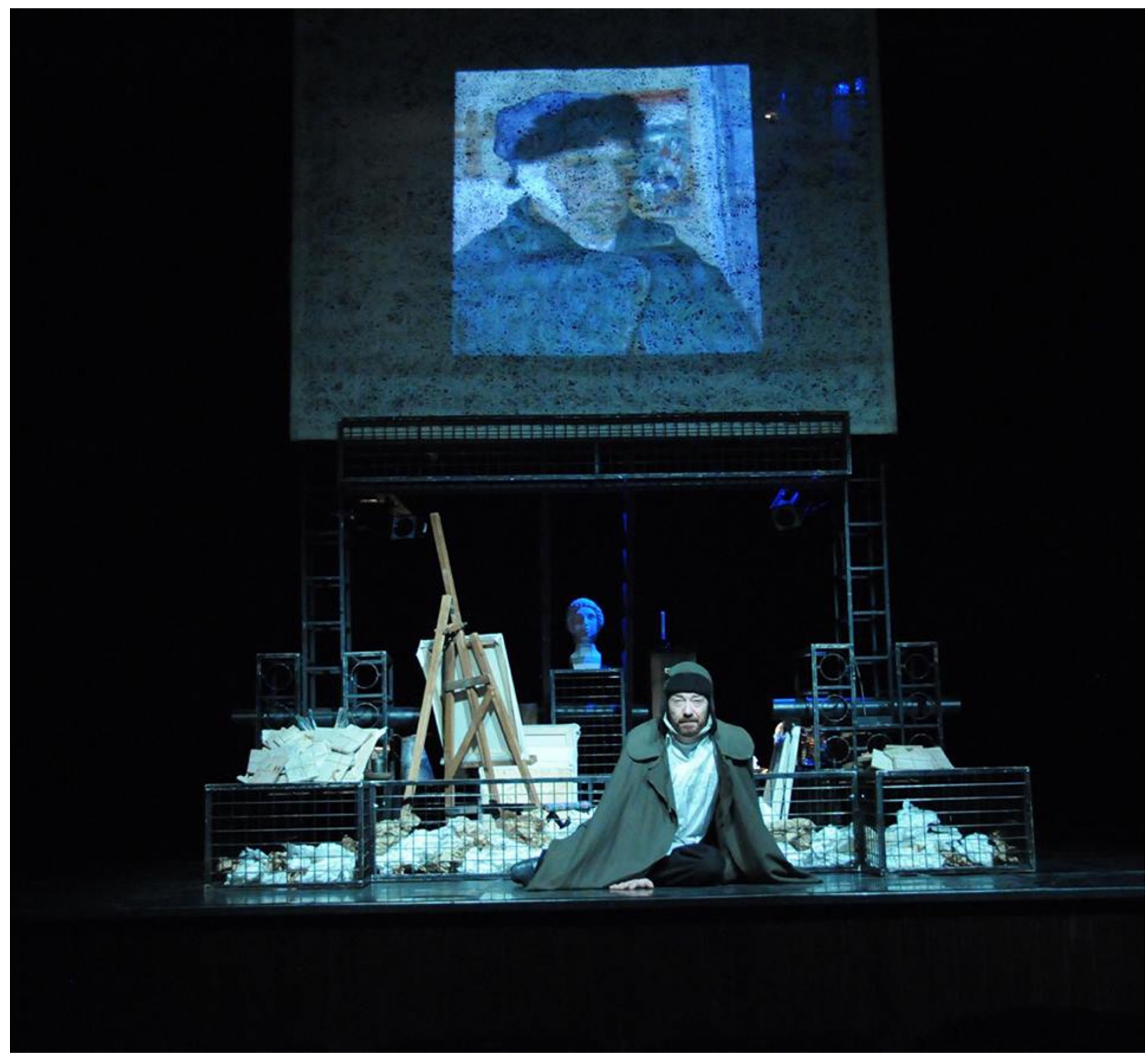

Şekil 2. Van Gogh, Tiyatro Gerçek, 2012 (Gerçek, 2012).

2012 yılında Tiyatro Gerçek tarafından sahnelenen, Gordon Smith'in yazdığı tek kişilik biyografik oyun olan 'Van Gogh'un (bkz. Şekil 2) sahne tasarımı Nurullah Tuncer tarafından yapılmıştır. Oyun sırasında ünlü ressamın hayatından kesitler Hakan Gerçek'in ünlü ressamı canlandırmasıyla anlatılırken, anlatıyı oluşturan zaman dilimleri sahne üzerine yerleştirilen beyaz perdeye yansıtılan resimlerle görselleştirilmiştir. Oyunda kronolojik bir biçimde Van Gogh'un Paris'ten Arles'e taşınma süreci ve bu yeni kentteki yaşamı anlatılırken, dekorda ressamın atölyesini temsil edecek parçalar ile devasa bir tuval şeklinde kullanılan beyaz perdede gösterilen Van Gogh'un tabloları, O’nun bu dönemdeki hayatını resmetmektedir (Akmen, 2010).

\footnotetext{
2 Fovizm'in temsilcilerinden Henri Matisse, anti-natüralist renk anlayışında eserler vermiştir Az sayıda renkle zengin ve ritmik armoniler yaratmıştır.
} 


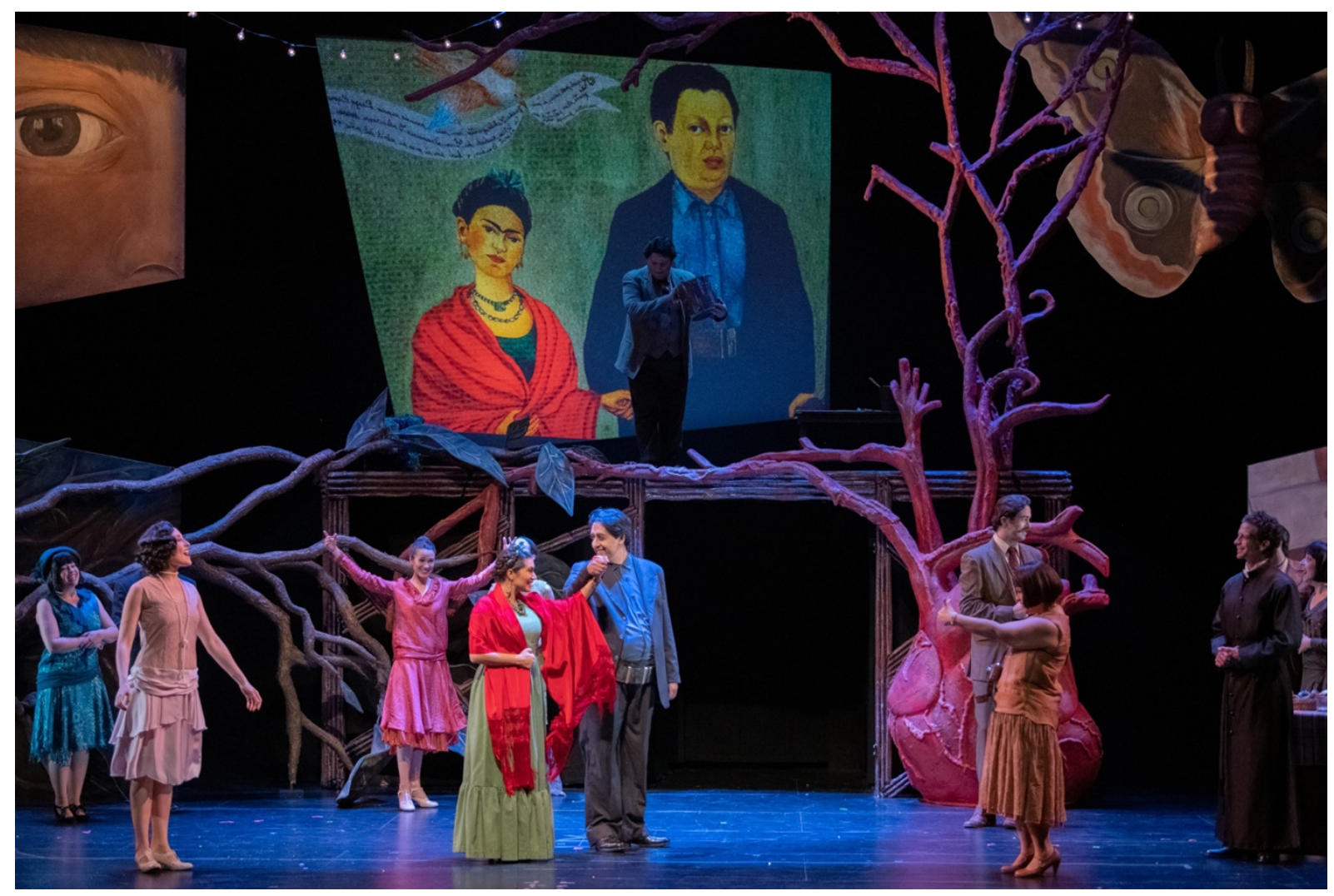

Şekil 3. Frida, Florida Grand Opera, 2019 (Kakol, 2019).

Frida Kahlo (1907-1954), çalkantılı ve acılı yaşam hikâyesi ile pek çok kez farklı ülkede, farklı yapımlarda tiyatro sahnesi üzerinde canlandırılmış bir ressamdır. Resimlerinde hep kendi portresini farklı sürrealist kompozisyonlarda gördüğümüz Kahlo'nun, hayatını dramatize eden bu tiyatro yapımlarında da sanatçının resimleri referans alınmıştır. Bu yapımlardan birine örnek olarak Florida Grand Opera'nın 2019'da sahnelediği 'Frida' oyununu (bkz. Şekil 3) ele alabiliriz. Yapımın dekor ve kostüm tasarımcısı Monika Essen, oyunda Frida Kahlo'nun yaşamından en önemli anları, dekor tasarımında onun resimlerinden parçalarla görselleştirmiştir. Kostüm tasarımları da otoportre resimlerde resmedilen kıyafetlere göre tasarlanmıștır. İki boyutlu olarak projeksiyonla sahne üzerinde büyük panellere yansitılan bu Frida Kahlo resimlerine ek olarak, resimlere yer yer görülen kelebek, kalp gibi nesneler de sahnede üç boyutlu olarak yer almıştır. Adeta Kahlo'nun resimlerinden üç boyutlu bir kolaj izlenimi veren sahne tasarımı, bu resimlerde ön plana çıkarılan detayları, ressamın hayatından kesitler gibi yansıtmıştır.

Soyut Ekspresyonizm akımına dâhil edilen ünlü ressam Mark Rothko'nun (1903-1970) hayatından bir kesitin konu edildiği 'Kırmızı' oyunu, daha çok sanat eserinin yaratım sürecine, resmin akımlar içindeki dönüşümüne, sanat-sermaye ilişkisine odaklanmaktadır. Oyun hem kurgusunda hem kişileștirmesinde öylesine yalın tasarlanmıştır ki sanatsal tartışmalara uzak izleyiciyi bile içine çekebilmektedir. Rothko, ününün doruğunda olduğu döneminde New York'taki Seagram binasının çatısında açlacak Four Seasons adlı bir restoran için duvar resimleri siparişi almış ve bu resimleri asistanı ile birlikte hazırlama sürecine girmiştir. Oyun, seyirciye bu resimlerin yaratılma sürecini dramatize ederek aktarılmaktadır. Böylece ressamın eseri ve çoğu eserin kullandığı kompozisyon odak noktasına alınmıştır. Soyut Ekspresyonizm akımında görülen resim görselliği kadar performans etmeni de böylece oyun aracılığı ile ön plana getirilmiştir. Oyunda özel yaşantısına dair hemen hiçbir bilginin bulunmaması ve atölye dışında bir yaşamın gösterilmemesi, Rothko'nun adeta atölyede yaşayan biri olarak sunulması ressamın son yıllarının oyuna kaynak oluşturduğunu göstermektedir. Oyunda Rotkho, kübizmi yıkan soyut ekspresyonizmin, yeni parlamakta olan pop-art tarafından yerinden edilmek üzere olduğu bir dönemde yapar Seagram binası resimlerini. Rotkho oyunda, resimleri üzerine uzun süre nasıl düşündüğünü, bunun resim yapmanın en önemli parçası olduğunu, katman katman defalarca boyayarak bir resmi oluşturduğunu anlatmaktadır. Seyirci de sahnede düşüncenin olgunlaşıp resme dönüşme anına ve bu anın kutsallığına, kırılganlığına da böylece şahit olmaktadır (Ünlü, 2015, s. 297-303). Böylece hem resmin bir replikası canlanmış hem de bu 
eserin olușturulma süreci ve motivasyonları sahne üzerinde canlandırılarak bir tasarım etmenine dönüşmektedir.

Marco Mammucci'nin yazdığı ve yönettiği 2016 yapımı 'Tu Me Fais Tourner La Tete' (Başımı Döndürüyorsun) adlı fiziksel tiyatro eseri, sürrealist ressam Marc Chagall'ın (1887-1985) oyun kişisi olarak canlandırıldığı ve resimlerindeki kompozisyonlarından yararlanıldığı bir fiziksel tiyatro örneğidir. Sözel anlatıdan çok fiziksel performansa odaklanan oyunda referans alınan Chagall resimlerinden figürler ve duruşlar sahnede görselleştirilmiştir. Sahne üzerinde dekor kullanımından ziyade, kostümler ve ışıklarla resimlerdeki atmosfer ve renkler yakalanmaya çalışılmıştır. Fiziksel kısımlar dışında, sözel anlatının oluşturduğu kısımlarda ise Marc Chagall'ın performe edilen resim kompozisyonlarını resmetme anları, tıpkı ressamın görsel dili gibi şiirsel özelliklerle anlatılmaktadır.

\section{Dramatik Anlatımın Sahne Fonundaki Resimlerle Görselleștirilmesi}

Resim kompozisyonlarının tiyatro sahnesine aktarılma sürecinde iki boyutlu fiziksel yapısı bozulmadan dramatik anlatıyla bütünleştirilmesi pek çok sahne yapımında tercih edilen bir yöntem olarak karşımıza çıkmaktadır. Özellikle modern dans gösterileri ve opera eserlerinin modern yorumlarında, gerek fiziksel koreografi ile gerek destansı anlatıyla görsel katman üzerinden paralellik kurabilecek resim kompozisyonları, sahne fonunda kullanılabilmektedir. Böylece dans gösterilerinde sahnenin fiziksel hareket alanının, opera eserinde ise kalabalık oyuncu kadrosunun oyun alanını kısıtlanmaması için sahne tasarımına referans olarak seçilen resim, sahnedeki diğer tasarım etmenleriyle estetik anlamda uyumlanacak biçimde sahne fonunda yerini almaktadır.

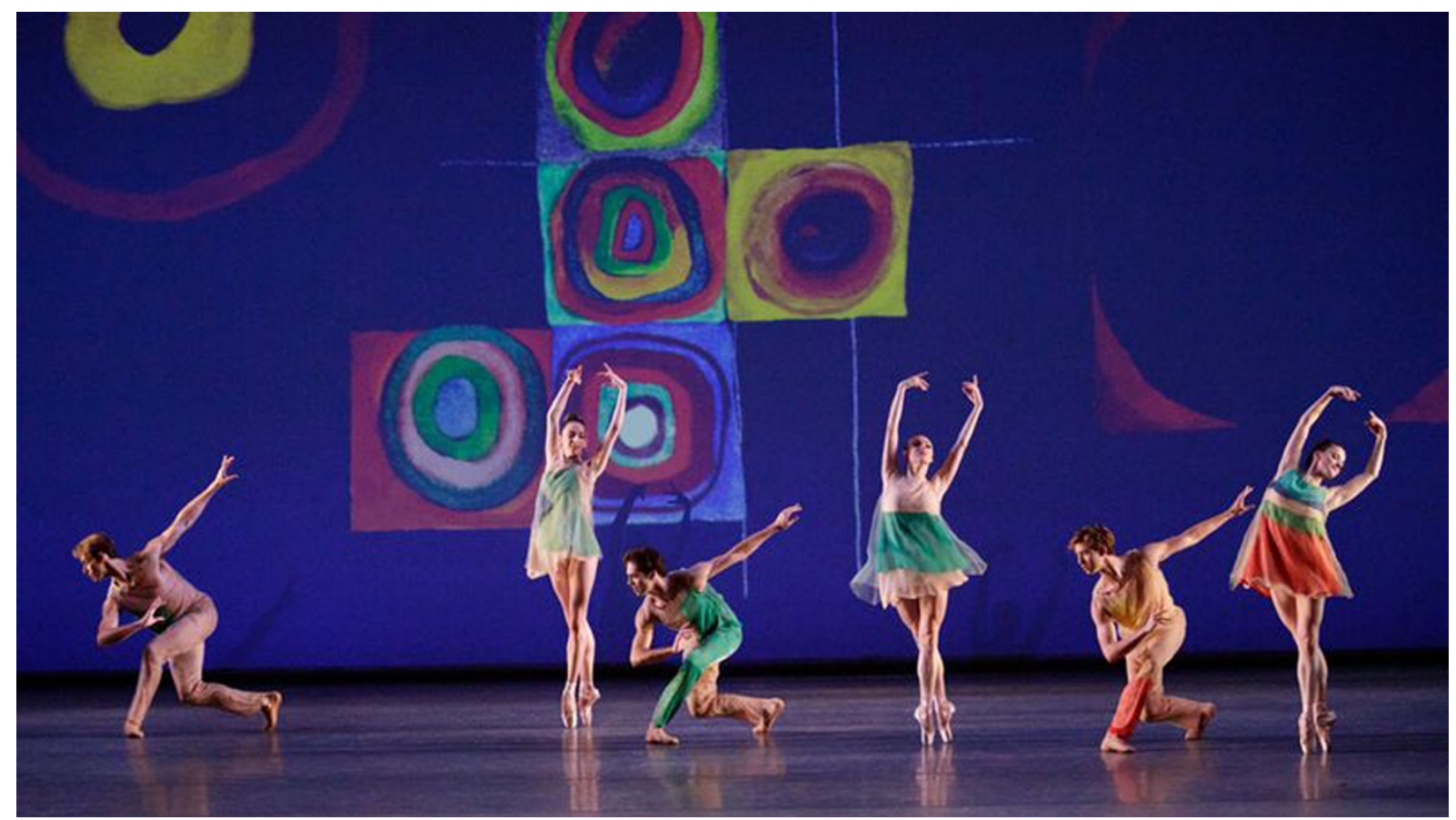

Şekil 4. Pictures at an Exhibition, New York City Ballet, 2014 (Kolnik, 2014).

Bu kullanıma bir örnek olarak 2014'te New York City Ballet tarafından gösterimi yapılan 'Pictures at an Exhibition' dans gösterisinde (bkz. Şekil 4), koreograf Alexei Ratmansky'nin düzenine uygun olarak sahne tasarımcı Wendall K. Harrington ise, Wassily Kandinsky'nin Color Study: Squares with Concentric Circles (1913) resminden parçaları, projeksiyon aracılı̆̆ı ile fonda iki boyutlu olarak kullanmıştır. Böylece Kandinsky'nin soyut sanata dair düşünceleriyle uyum göstererek renkler ve şekiller, hareket ve müzikle bütünleşmiştir. Wassily Kandinsky'nin, 1928 yılında Almanya Friedrich Tiyatrosu'nda gösterimi yapılan Modest Musorgski'nin 'The Great Gate of Kiev' eseri için sahne tasarımı öğesi olarak resmettiği soyut tablolar, sanatçının müzik-resim ilişkisine dair kuramsal fikirlerinin uygulaması olarak görülebilir. Kandinsky bu teorisinde, müzikal fikirleri ana renkler gibi işlemektedir. Soyut resimleri seslerle bütünleştirmektedir. 'Pictures at an Exhibition' eserinin sahne uyarlamasında da sahne tasarımı olarak hareketli resimler yapma firsatı bulmuştur. Kandinsky, Mussorgsky'nin eserini Hartmann'ın temsili üslubuna geri çevirmek yerine, Bauhaus okulunun sözlügünden geometrik figürlerin operatik bir hareketini 
yaratmıştır. Anlatı oluşturmak yerine, müziği resme dönüștürmüștür. 2014 yılında yeniden 'Pictures at an Exhibition' ismiyle sahnelenen dans gösterisinde de Kandinsky'nin soyut görsel dili kullanılarak, sanatçının resim kompozisyonlarında yer alan kare ve yuvarlak parçaların sahne değişimlerine göre, parçalı olarak farklı kombinasyonlarda kullanıldığı bir örnek olmuştur. Dansçıların kostüm tasarımlarındaki renkler de bu şekillerin renkleriyle uyumlu olacak şekilde tasarlanmıştır (Battista, 2016).

Resim kompozisyonlarının bale gösterimlerinde sahne tasarımının önemli parçası olduğu örneklerden bir diğeri ise 2014 yılında Compagnia Finzi Pasca ekibinin sahnelediği ‘La Verita’ gösterisidir. Salvador Dali’nin (1904-1989) Mad Tristan ve İsolde (1944) resimlerinden esinlenen sahne tasarımcısı Hugo Gargiulo ve kostüm tasarımcısı Giovanna Buzzi, gösteride yer yer kostüm ve aksesuar tasarımlarında da bu resimdeki figürleri üç boyutlu olarak sahnede hareketlendirilecek şekilde hayata geçirmiştir (Sullivan, 2016). Bu tasarım yöntemine bir diğer örnek ise yönetmen ve koreograf Paulo Bortoluzzi'nin 1986'da sahnelediği 'Picasso'ya Saygı' adlı dans gösterisidir. Performansın odak noktası, yapımın isminden anlaşılacağı üzere Picasso'nun resimlerinde yarattığı kübik imgeler ve figürlerdir. Yapımın sahne tasarımcısı Beni Montresor da, bu görselliği yaratmak adına Picasso'nun resim kompozisyonlarını bütünlüklü olarak sahne fonunda sergilemektense, resimlerdeki kübik figürlerden ve nesnelerden parçaları büyük boyutlarda monokrom ve iki boyutlu olarak yeniden yorumlamıştır.

Kübizm akımının önde gelen ismi Pablo Picasso'nun resimlerinden kompozisyonlar veya bu resimleri oluşturan etmenler de sahne görselliğinde kaynak eser olarak çeșitli yapımlarda kullanılagelmiştir. 26 Nisan 1937 yılında Bask bölgesindeki Guernica kentinin General Franco yanlısı Alman uçakları tarafından yerle bir edilmesi üzerine Picasso, Guernica (1937) resmine başlamıştır. Resim birçok tartışmaya yol açmasına rağmen kısa sürede efsaneleșmiştir. Sanat tarihinde belirgin bir yeri olan Guernica, özelde faşizmin, genelde ise modern savaşın acımasızlığına karşı sürekli bir protesto olarak görülmüştür. Guernica'yı yaparken Picasso zaten kafasında bulunan görünüşte çok farklı olan bir temada uyguladığı özel imgeleri kullanmıştır. Guernica, Picasso'nun acı çekmeyi nasıl imgelediği hakkında bir resimdir. 2009 yılında Teatro Regio di Parma tarafında sahnelenen 'I Lombardi alla Prima Crociata' (İlk Haçlı Seferinde Lombard'lar) eserinde (bkz. Şekil 5), Paolo Bregni sahne tasarımını gerçekleştirmiştir. Bu eserde Picasso'nun Guernica resmi, ışık yansıtmasıyla büyük ölçekte kullanılmıştır. Eserin savaş teması ile örtüşecek biçimde, savaşın trajik tarafı bu şekilde simgesel olarak tekrar sahnede resmedilmiştir (Franceschini, 2009).

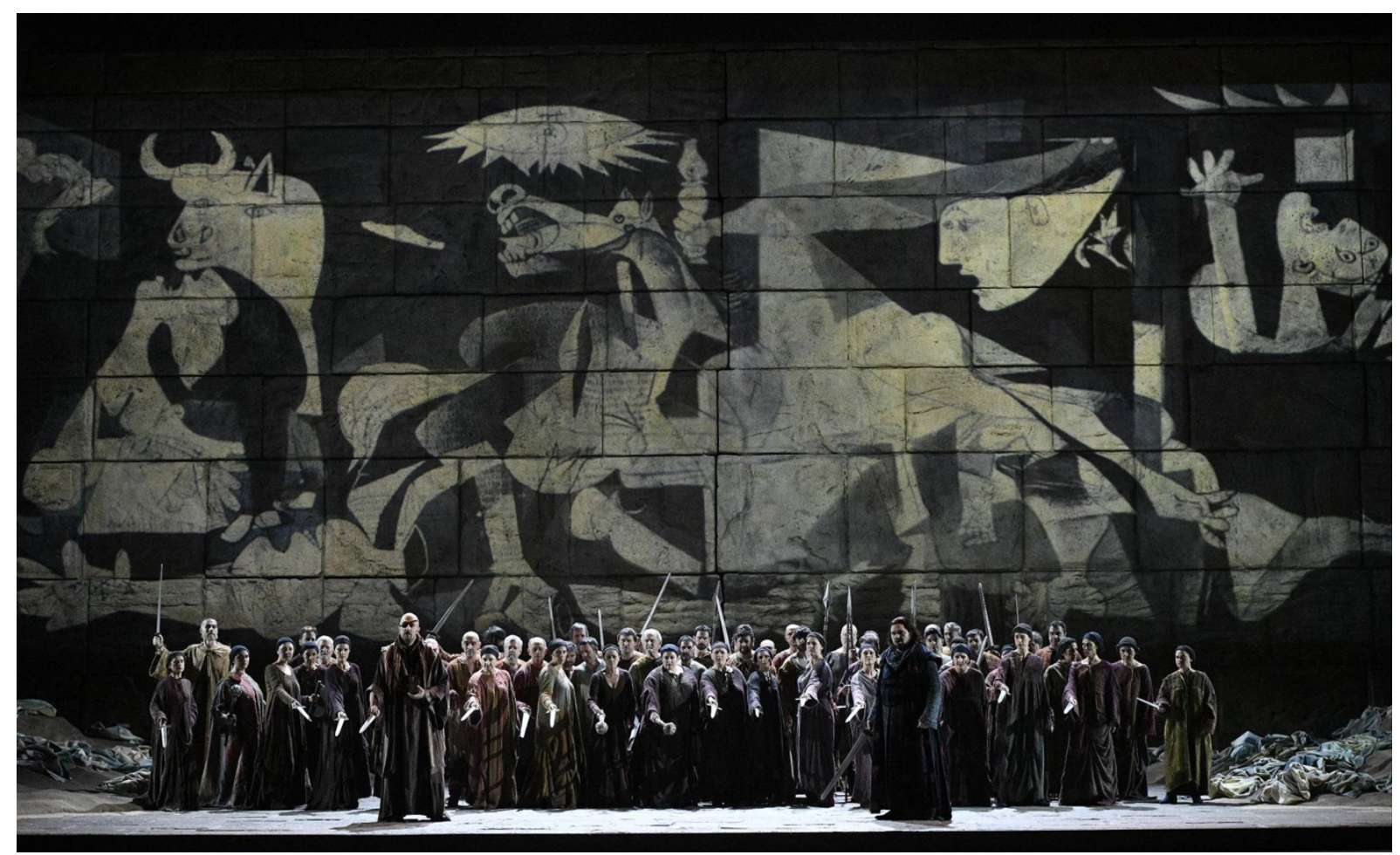

Şekil 5. I Lombardi alla Prima Crociata, Teatro Regio di Parma, 2009 (Ricci, 2009). 


\section{Farklı Resim Kompozisyonlarının Bir Sahne Tasarımında Buluşması}

Tiyatro yapımları için üretilen sahne tasarımlarında kullanılan resim yapıtlarının, eserin sanatçısından bağımsız olarak sözel anlatı oluşturulmuş bir oyunda kullanımlarına değinilecek bu bölümde, performans alanını görselleştiren veya şekillendiren farklı dönemlere ve sanatçılara ait birden fazla eserin sahnede kullanımına odaklanılacaktır. Kompozisyon bütünlüklerinin bozulmadan farklı resimlerin mekân veya atmosfer oluşturma amaçlı sahnede kullanımlarında dikkat edilen hususlar genellikle sahne tasarımında yer alan bu resimlerin stil, renk, estetik gibi açılardan birbiriyle uyumlu olmasıdır. Birden fazla resim kompozisyonunun kullanımı sahne değişimlerine göre sıralanan eserler veya farklı resimlerden alınan görsel etmenlerin tek mekânda buluşturulması da olabilmektedir.

Bu özelliklerde sahne tasarımlarına ilk örnek olarak Opera Philadelphia'nın 2018 yılında sahnelediği 'La Boheme' yapımında (bkz. Şekil 6), projeksiyonla sahne değişimlerine göre yansıtılan empresyonizm resim örnekleri, oyun atmosferini vurgulamak ve mekânsal özellikleri görselleștirmek üzere tercih edilmiştir. Oyununun sahne ve kostüm tasarımcısı Davide Livermore, mekan değişimleri ve atmosfer yaratımı amacıyla sahneye projeksiyon ışıklandırmasıyla tablolar şeklinde yansıtılacak resimleri ünlü empresyonist ressamların meşhur eserlerinden seçmiştir. Bunlar arasında Camille Pissarro'nun Güneşli Öğleden Sonra Fuar (1901) ve Opera Caddesi'nde Güneşli Sabah (1898) tabloları, Pierre Auguste Renoir'nın Anemonlar (1898) tablosu, Vincent Van Gogh'un Yıldızlı Gece (1889) ve Ayçiçekleri (1888) tabloları bulunmaktadır. Resim kompozisyonları renk veya biçim olarak değiştirilmeden olduklarından büyük boyutlarda tasarım öğesi olarak kullanılmış ve oyun içerisinde hem mekân betimlemelerine hem de duygu durumlarının ifadesine karşılık gelecek biçimde kullanılmıştır (Sekoff, 2017).

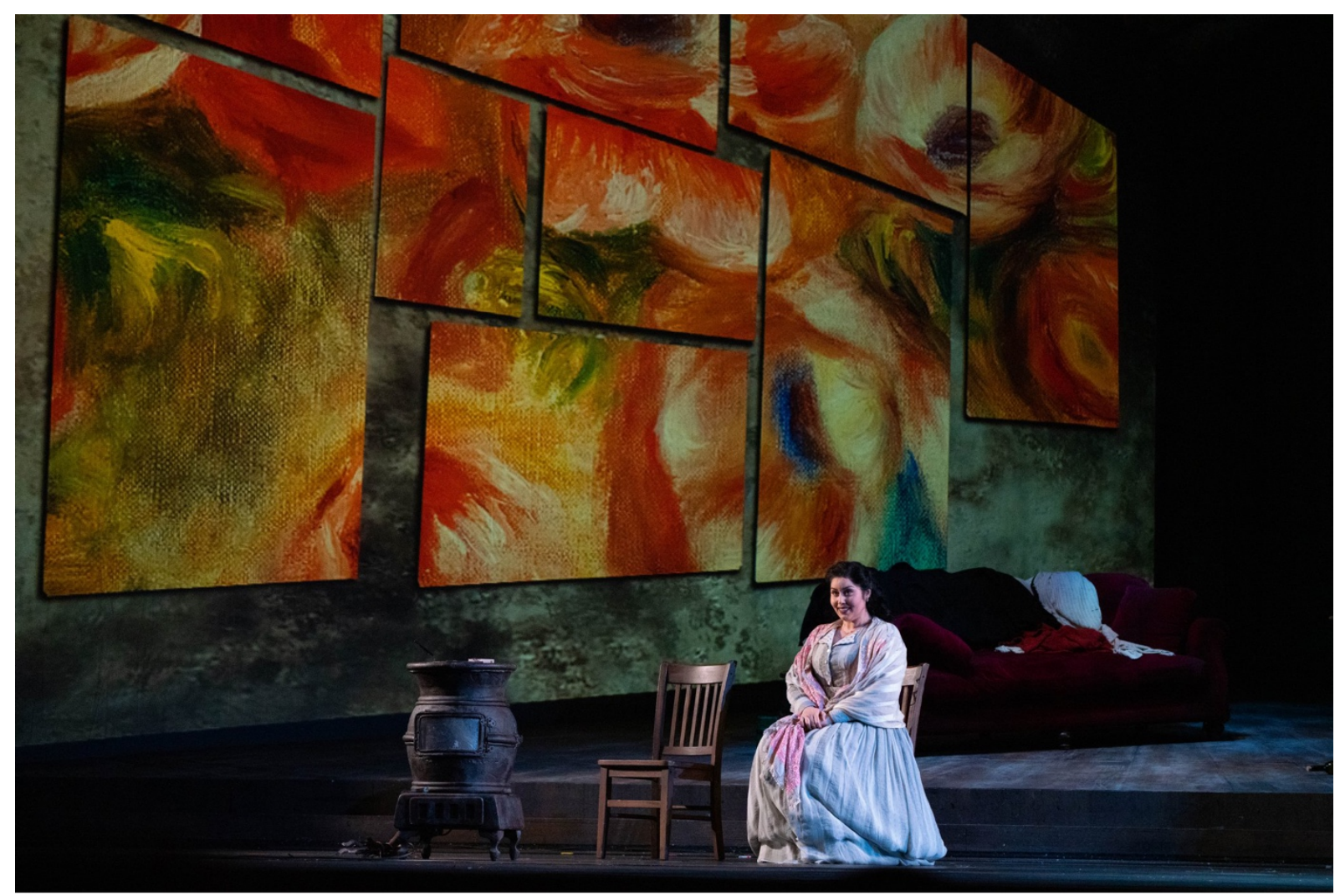

Şekil 6. La Boheme, Opera Philadelphia, 2018 (Pisano, 2018).

Gerçeküstücülük akımının önemli temsilcilerinden ressam Rene Magritte'in (1898-1967) resim kompozisyonları sinema ve tiyatro alanında pek çok esere ilham kaynağı olmuştur. Sahne sanatları özelinde bakacak olursak bu örneklerden ilki, Magritte'in 1960 yılında resmettiği The Postcard (1960) isimli tablonun görsel olarak referans alındığı, 1990 yılında Ralph Koltai'nin sahne tasarımıyla The Royal Ballet'in sahnelediği ‘The Planets' isimli eserdir. Bu tasarımda Rene Magritte'in sürrealist resminin odağında yer alan yeşil elma figürü, Ralph Kotai'nin sahne tasarımı fonunda gökyüzü perdesine resimdeki benzer oranlar ve renklerde yerleştirilmiştir. Resim kompozisyonunda bulunan insan figürünün nesneleri ölçeklendirmemizi sağlaması sayesinde, gökyüzünde devasa bir elmanın süzüldüğü algılanmakta ve sahnede yaratılan 
görsellikte de sahne ölçeklendirmesi bu algıya göre oluşturulmaktadır. Odaktaki elma figürü haricinde resimde görülen mekânsal unsurlar, sahne tasarımında çıkarılmıştır. Sahne zemini ise dans gösterisindeki hızlı ve geniş hareketlere alan sağlayacak ölçüde boş bırakılmıştır.

Dalhouise Opera'nın 2016 yapımı Mozart'ın 'Sihirli Flüt' adlı eserinin yorumunda ise sahne tasarımı, yine Rene Magritte kompozisyonlarından izler taşımaktadır. Özellikle ressamın Galconda (1953) ve The Son of Man (1964) isimli resimlerindeki figürler, dekor ve kostüm tasarımlarında, anlatı ile bütünlük oluşturacak şekilde yerleştirilmiştir. State Theatre Company'nin 1990'da Avustralya'da sahnelediği William Shakespeare'in 'Yanlışlıklar Komedyası' oyununda da sahne tasarımcıları Shaun Gurton ve Browyn Jones, mekân ve atmosferin görselliğinin oluşturulması aşamasında Rene Magritte eserlerinden ilham almıştır.

Rene Magritte'in resimlerinden yola çıkılarak oluşturulmuş sahne tasarımlarına son örnek olarak, Maryland Opera Stüdyosu'nun 2004 yılında sahnelediği 'Hoffmann Masalları' yapımı (bkz. Şekil 7) gösterilebilir. Sahne tasarımcısı Erhard Rom bu oyun için dekor ve kostüm tasarımlarını oluştururken Magritte'in birden fazla resminden yararlanmıştır. Referans eserler arasında sanatçının The Evening Gown (1954), The Wasted Effort (1954), Beautiful World (1962), La Goutte D'eau (1948), The False Mirror (1928), Black Magic (1945), The Human Condition (1935) adlı resimleri bulunmaktadır. Renk ve biçim açısından birbiriyle uyumlu resim etmenleri kaynaştırılarak, sahne üzerinde gerçeküstü bir atmosfer oluşturulması amaçlanmış ve oyunun masalsı anlatımıyla bütünlük oluşturması sağlanmıştır.

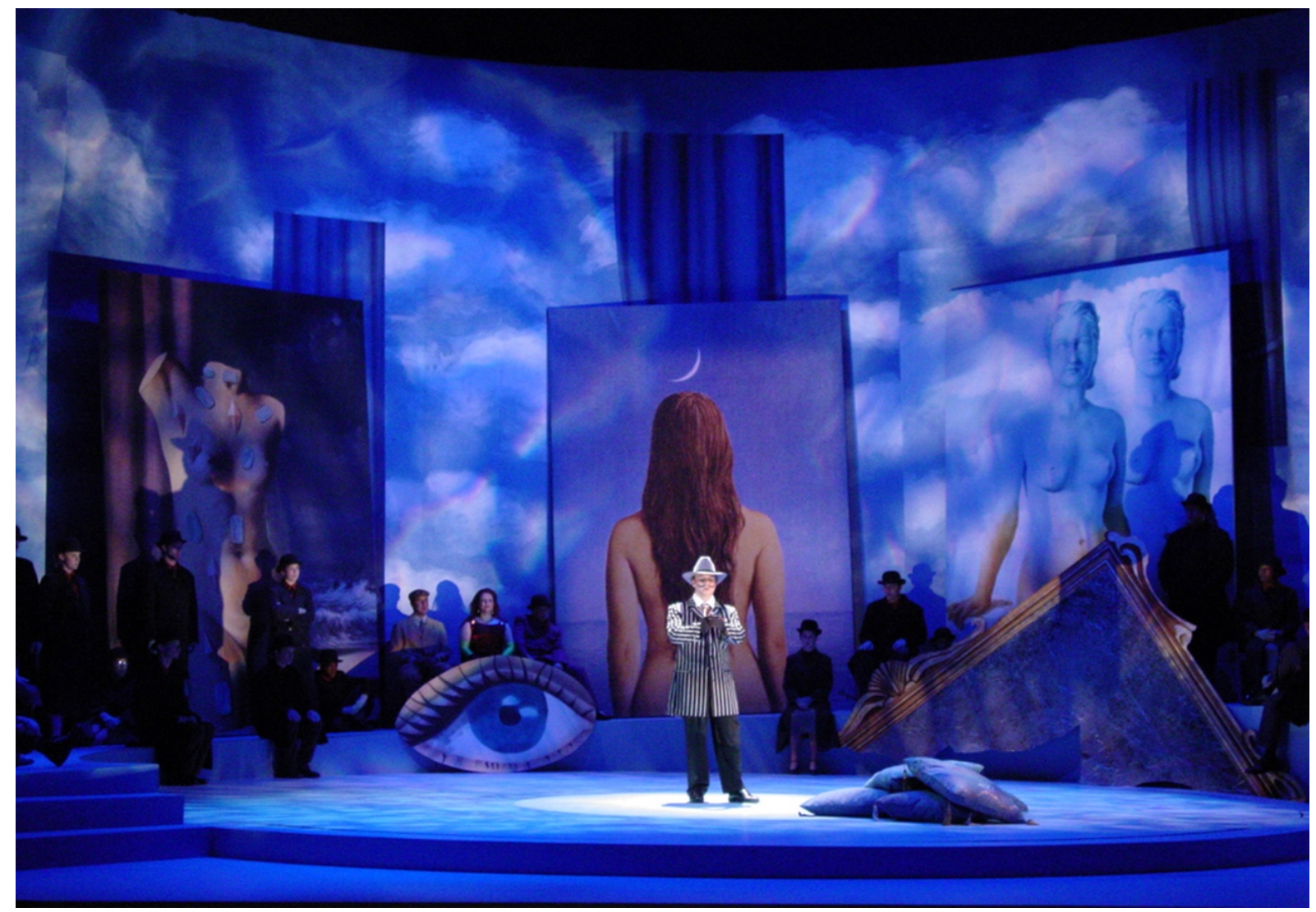

Şekil 7. Hoffmann Masalları, Maryland Opera Stüdyosu, 2004 (Raley, 2004).

Canadian Opera Company'nin 2015 senesinde sahnelediği 'Pyramus and Thisbe' eserinde (bkz. Şekil 8) sahne görselliği bütünüyle soyut dişavurumcu ressam Mark Rothko'nun üslubundan esinlenilerek tasarlanmıştır. Sahne tasarımını Paul Steinberg'in ve kostüm tasarımlarını Terese Wadden'in gerçekleştirdiği oyunda tamamen boş bir sahnede merkeze yerleştirilmiş uzun ve alçak bir platform ve dikey büyük duvar parçaları vardır. Sahnenin arka duvarı, Mark Rothko'nun resimlerini anımsatan büyük renk blokları şeklinde boyanmıştır. Sanatçının eserlerinde baskın olarak gördüğümüz biçimlendirme, opera sahnesinde devasa ahşap panolar üzerinde kullanılınca hem klasik esere modern bir görsel yorum katmış hem de renklerin yoğunluğu sayesinde dramatik anlatıya yeni bir katman sağlamıştır. Böylece resim, Pyramus ve Thisbe'nin bir duvarla ayrılmasını ve ölümdeki nihai birlikteliğini soyut olarak ifade etmektedir (Vincent, 2015). 


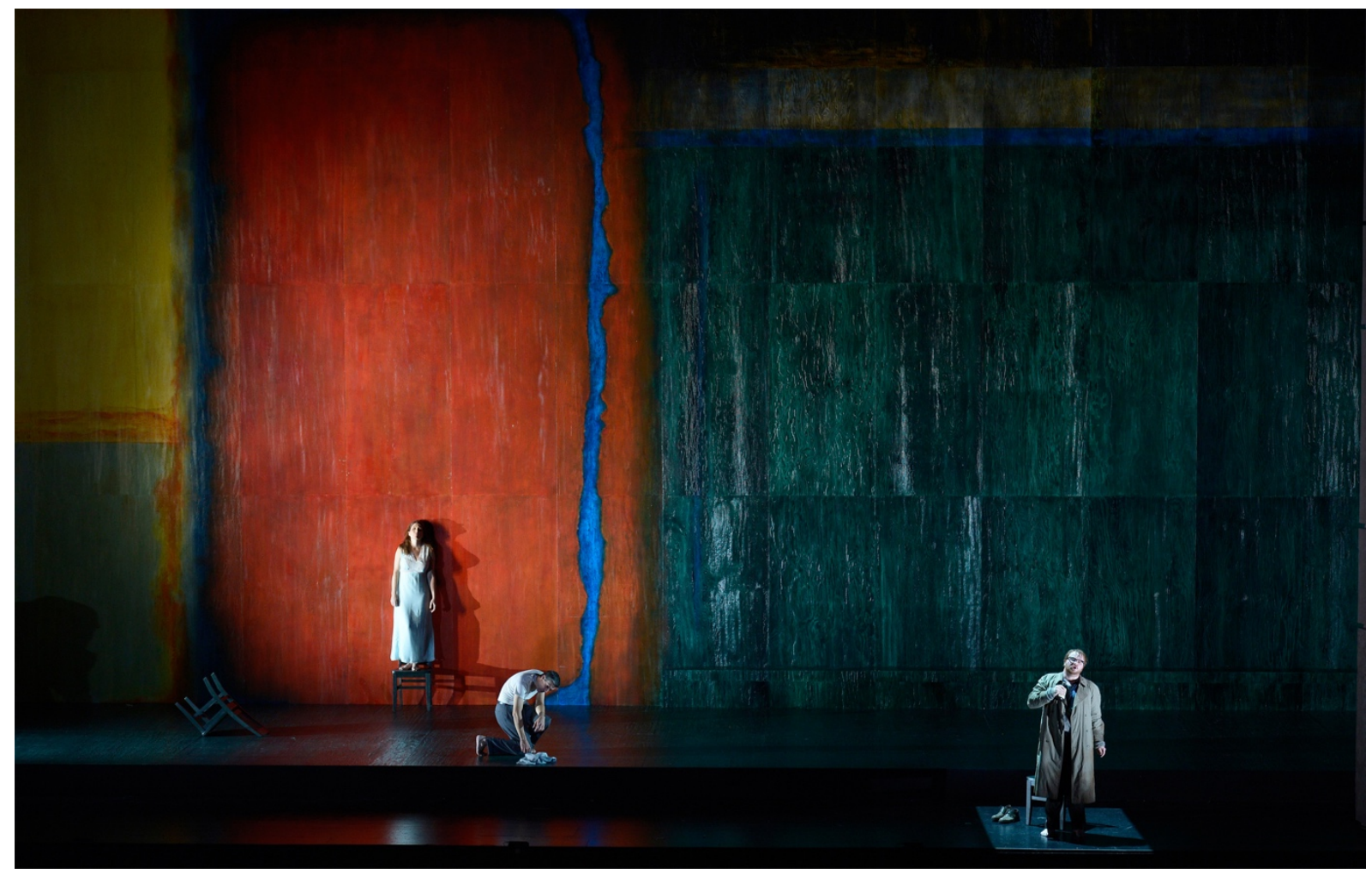

Şekil 8. Pyramus ve Thisbe, Canadian Opera Company, 2015 (Beechey, 2015).

\section{Sahne Tasarımında Mekan Öğesi Olarak Kullanılan Resim Referansları}

Modern resim akımlarında gerçekliğin kırılması ve daha soyut anlatımlara yer verilmesi gözlemlenmektedir. Bu eğilim resimlerde tasvir edilen iç veya dış dünya görüntülerinin daha yenilikçi ve sanatçı özgü estetikle yaratılmasını sağlamıştır. Sanatçılar çoğu zaman resimlerinde kullandıkları mekânları veya uzamları da özgün çizgi, boyut ve renk kullanımları ile oluşturmuşlardır. Resmettikleri mekânların ve nesnelerin biçimine de duygu durumlarını görsel olarak yerleştirmişlerdir. Sahne tasarımlarında görülen resim referanslarında ise mekânı ve atmosferi tanımlayacak türden resim taklitleri, kaynak alınan resmin iki boyutlu yapısına üçüncü boyutu katarak sahne uzamına tamamen yerleştirilerek elde edilmiştir.

Resim kompozisyonlarının veya figürlerinin iki boyutlu, yüzeysel formundan slyrllarak sahne hacmine yayıldığı veya oyuncular tarafından bedene kavuşturulduğu sahne tasarımlarına örnek olarak "André Chénier" yapımı incelenebilir. Avusturya'nın Bregenz şehrinde her yıl ağustos ayında düzenlenen Bregenz Festivali, dünyanın en büyük yüzen sahnesinde gerçekleşmektedir. Her sene etkileyici ve devasa sahne tasarımlarına ev sahipliği yapan bu festivalin yapımları arasında 2012'de sahnelenen 'André Chénier' operası yer almaktadır. Bu yapımın sahne tasarımında neo-klasik dönemi ressamlarından Jacques Louis David'in (1748-1825) Marat'ın Ölümü (1793) adlı tablosundan esinlenilmiştir. Bu tabloda yer alan figürün büyük ölçekte üç boyutlu olarak inşa edilmesi sonucunda, oyun sahnelerinin üzerinde oynanabileceği anatomik bir platform oluşmuştur. Oyuncular da bu devasa beden üzerinde oynamaktadır. Klasik resimde gördüğümüz iki boyutlu görüntü, adeta bir heykel gibi üç boyuta kavuşmuş ve opera sahnesine dönüşmüştür (Filippetti, 2011).

Modern resim örnekleri üzerinden bakacak olursak; 2012'de San Francisco Opera yapımı Verdi'nin 'Rigoletto' sahnelemesinde (bkz. Şekil 9), sahne tasarımını gerçekleştiren Micheal Yeargen, Giorgio de Chirico'nun (1888-1978) metafizik resimlerindeki mekanlar, perspektif ve mimarisinden etkilenmiştir. Tasarımcı, sahne ışıklamasında da metafizik resimlerdeki atmosferi yakalayabilmeyi amaçlamıştır. Giorgio de Chirico'nun resimlerinde gördügüüüz bina yapıları, ışık kontrastları ve renk geçişleri bu oyunun dramatizasyonunda belirgin olarak yer almaktadır. Bu sahne tasarımında gördüğümüz yaklaşım, referans alınan bu resim kompozisyonlarından sadece mekân ve ışığa dair elementleri kullanarak atmosferi oluşturmaya yöneliktir (Hodge, 2012). 


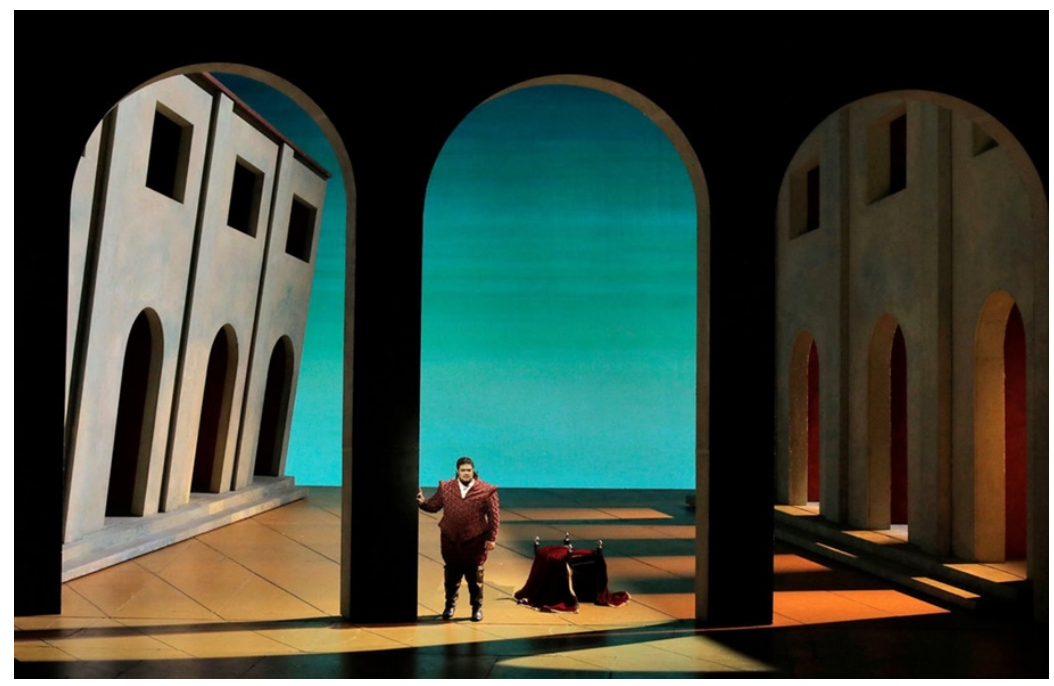

Şekil 9. Rigoletto, San Francisco Opera, 2012 (Weaver, 2017).

Sahne tasarımcısı Klaus Grünberg ise, Vocal Theatre Carmina Slovenica ekibinin Heiner Goebes yönetmenliğinde 2012'de sahnelediği ‘When the Mountain Changed its Closed' oyununda, Henri Rousseau 'nun (1944-1910) 'Ormandaki Aslan' resmini mistik mekân yaratmak için birebir kullanmıştır. Performans sırasında mekân yaratma amacıyla farklı ressamların eserlerinden de yararlanılmıștır. Henri Rousseau'nun resminin kullanıldığı sahnede, resimde yer alan aslan figürü çıkartılmıştır. Böylece resim sadece mekânı belirtici bir öğe olarak fonda yer almış ve görsel betimlemeler olarak oyunla bütünleşmesi sağlanmıştır.

İstanbul Oyun Atölyesi'nin 2008 yılı yapımı 'Testosteron' oyun gösteriminde sahne tasarımcı Bengi Günay, sahne görselleştirmesinde Salvador Dali'nin Mae West'in Yüzü (1934) adlı tablosundan yararlanmıştır. Resimdeki üç boyut etkisi, sahne derinliğine katmanlı şekilde yayarak, oyun boyunca başroldeki erkeklerin, kadınlarla iliş̧ileri üzerinden yaratılan komedi ve çatışmayı bu resim üzerinden sembolleştirerek çerçevelemiştir.

Henrik İbsen'in 'Bir Bebek Evi' (1879) adlı oyunu (bkz. Şekil 10) Huntington Theatre Company tarafından 2016 yılında sahnelenmiştir. Bu yapımda ise sahne tasarımını gerçekleştiren James Noone, atmosfer yaratımı açısından sahnenin gökyüzü perdesinin renklendirilmesinde Edvard Munch'un Çı̆̆lık (1893) tablosunun renkleri ve çizgilerinden yararlanmıștır. Dekorun üç boyutlu formunu oluşturulan ve oyunun tek mekân olarak geçtiği ev bir kesit olarak tüm iç mekânı görülecek şekilde tasarlanmıştır. Bu evin arkasındaki gökyüzü perdesinde ise dış dünyanın korkutuculuğu ve gerginliğini "Çığlık" tablosundaki sıcak renklerdeki dalgalı çizgilerden oluşan gökyüzü tasviri yer almaktadır.

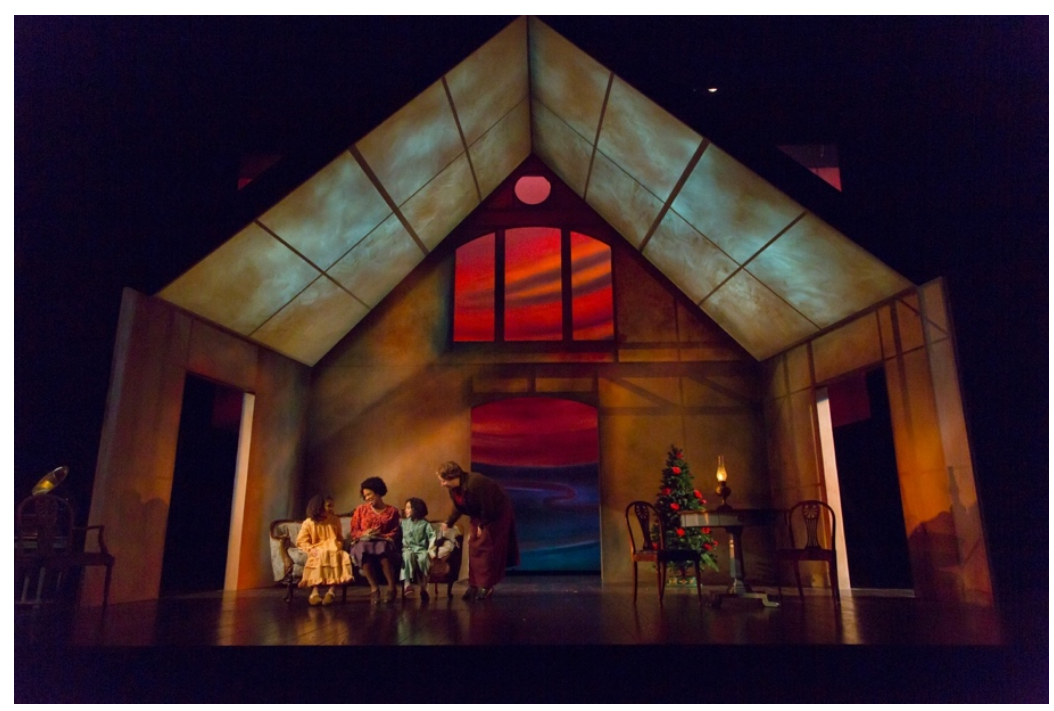

Şekil 10. Bir Bebek Evi, Huntington Theatre Company, 2016 (Erickson, 2016). 


\section{Resim Üsluplarının Kostüm Tasarımlarıyla Etkileşimi}

Figüratif resimlerde görülen kompozisyonlar genellikle bir tiyatro sahnesini andıracak şekilde dramatize edilerek kurulmaktadır. Bu algıyı özellikle klasik, barok ve romantik resimlerde görülen duruşlar, tavırlar, mekân yerleştirmeleri ve gerçekliği en estetik biçimde yorumlama tercihleri oluşturmaktadır. Micheal Fried, 18. yüzyıl Fransız Resim Sanatı üzerine yazdığı 'Absorption and Theatricality: Painting and Beholder in the Age of Diderot' (İçe Kapanma ve Teatrallik: Diderot Çağında Resim ve Resme Bakan) adlı kitabında, mizansende bașka birinin algısıyla ortaya çıkan bir olumsuzluktan bahsetmektedir. 0, "teatral" kavramını birçok resimde görebileceğimiz figürler için kullanmıştır. Güçlü renklerle resmedilmiş figürler sanki kendilerinin bir ressam tarafından çizildiklerinin farkındaymış gibi dururlar. Böylece teatral olarak sınıflandırılabilirler. Onların davranış tarzları önceden kurgulanmıştır. Fried, bu tür teatral davranışlar sergileyen figürlere içe kapanan davranışlar gösteren figürlerden daha düşük bir değer atfetmektedir (Fischer-Lichte, 2016, s. 318). Kalabalık figür mizansenleri içeren klasik resim kompozisyonlarında gözlemlenen bu tür teatral sahneler, sonrasında tiyatro sahnesinde çeşitli tabloların yeniden canlandırılması şeklinde performans ekiplerine ilham vermiş ve böylece bir sahneleme geleneğini açığa çıkarmıştır.

Tableau Vivant, 18. yüzyılda doğmuş, 1900'lerin başında Avrupa'da geliștirilmiş ve daha sonra Ro.Go.Pa.G (1963) ismindeki orta uzunlukta filmde yer almış ve çeşitli sanatçılar tarafından kullanılagelmiş eski ama etkileyici bir modalitedir. 'Canlı resim' olarak tanımlanan 'tableau vivant' tekniği, bir veya birden fazla aktör veya model içeren statik bir sahnelemedir. Bu gösteriler genellikle kostümlü, dikkatlice pozlanmış, sahne veya manzaraya sahip olarak sabit ve sessiz özelliktedir. Tiyatro ve görsel sanatların yönlerini birleştiren ara form gibi ele alınabilir. Örneğin; 2011'de İtalya'da projelerine başlayan Teatri 35 ekibi, bu tekniği yaşatan ve çeşitli festivallerde sergileyen bir gruptur. Ekibin şu ana kadar tablolarını canlandırdığı usta ressamlar arasında Leonardo Da Vinci, Raffaello, Michelangelo ve Caravaggio vardır. Ekip, bu ressamların en ünlü ve figür sayısı bakımından kalabalık tablolarını sadece tiyatro sahnesi değil, kilise, şehir meydanı gibi çeşitli alanlarda da canlandırmışlardır. Bu gösterimler tablolardaki mekân görselliğini ön plana çıkararak değil, kostüm, aksesuar ve figür duruşlarının kompozisyondaki gerçeğine uygun olmasına dikkat edilerek gerçekleştirilmektedir. Örneğin; 'Caravaggio's Tableaux Vivants' adlı gösterimde 15'e yakın Caravaggio tablosu klasik müzik eşliğinde iki dakikalık aralıklarla canlandırılmakta ve sahnelenmektedir.

Bu 'Canlı Resim' tekniği yașatan ve amatör sahne oyuncularının da dâhil olduğu çeșitli tiyatro ve festival yapımları da mevcuttur. Bunlar arasında Pageant of Masters (Ustalar Geçidi) sayılabilmektedir. 1933 yılında itibaren Amerika Birleşik Devleti'nin California eyaletinde Sanat Festivali olarak düzenlenen bu etkinlikte, pek çok sanatçı klasik tabloları, mekân görselliğini de büyük bir çerçeve içerisinde az bir derinlikle sağlayarak canlandırmaktadır. Burada canlandırmadan kasıt, sahne üzerinde yaklaşık bir dakikalık sürelerle, tablolardaki figürlerin, resme uygun duruşlarda hareketsiz olarak kompozisyonu büyük boyutlarda, resim estetiğiyle oluşturmasıdır. Bu tekniğin dramatik bütünlüklü bir tiyatro eseri içerisinde kullanımına ise yine Amerika Birleşik Devletleri, Güney Carolina eyaletinde 2020'de sahnelenmiş 'Living Gallery' isimli yapım gösterilebilir. Bu yapımın sahne tasarımı için seçilen resim kompozisyonları ise oyunun dramatizasyonuna göre İncil anlatılarının tasvir edildiği Rönesans tablolarıdır. Bu yapımda oyuncuların canlandırdığı tarihsel karakterler, ara sahnelerde bu teknikle üç boyutlu tabloları oluşturmaktadır. Kostüm ve makyaj tasarımları da resimsel bütünlüğü tamamlayacak şekilde fırça darbeleriyle biçimlendirilerek boyanmış ve renklendirilmiştir.

Stardust Theatre'ın 2006 yılında sahnelediği 'Rembrandt Müzikali'nde ise barok ressamın çalkantılı yaşamına yeni bir şaşırtıcı bakış getirilmektedir. Müzikalin sahne tasarımında yer yer dönemin mimarisini yansıtan işlemeler kullanılmıştır. Kostüm tasarımında da 17. yüzyıl dönemi kıyafetlerine uygun üslup kullanılmıștır. Bazı sahnelerde Rembrandt'ın (1606-1669) resimlerinden portreler fon perdesine yansıtılmıştır. Koreografide ise Rembrandt'ın en meşhur ve en kalabalık resimlerinden Gece Devriyesi (1642)'nin canlandırması mevcuttur. Bu sahnede resim kompozisyonunda görülen tüm karakterlerin yerleşimi, sahnede birebir resmedilmiştir.

Neo-Empresyonizm'in de öncüsü sayılan Georges Seurat, sanatsal ve bilimsel bir teknik olan Noktacıllk'a (Pointillism) öncülük etmiştir. Bu teknikle paletindeki renklerin ayrı ayrı duygular taşımasını ve belirli optik bir sistem yaratmayı amaçlamıştır. Sanatçı, her rengin izleyicide neşe, acı, hüzün gibi farklı duygular

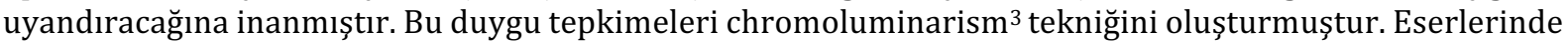

\footnotetext{
3 Renklerin optik olarak etkileşime giren ayrı noktalara veya yamalara ayrılmasıyla tanımlanan Neo-Empresyonist resimdeki karakteristik stildir.
} 
hacimli biçimler uzaktan bakıldığı zaman ton değişiklikleri yaratarak birbiriyle bütünleşen renkler, form kazanan nesneler ve hacimsellik veren farklı renk noktalarından oluşmaktadır. Ayrıca Seurat, Kübizm ve Konstrüktivizm gibi akımların habercisi olma niteliği taşımaktadır. 1884-86 yıllarında yaptığı 'La Grande Jatte Adasında Bir Pazar Öğleden Sonrası' isimli tablosu gerçek hayattan alınarak yapılmış eskizlerden oluşmaktadır. Resim bir adanın dingin bir köșesini gösterir ve kentlilerden oluşan bir kalabalık, güzel havanın keyfini çıkarmaktadır (Midgette, 2014).

Stephen Sondheim'ın kaleme aldığı 'George ile Parkta Bir Pazar' adlı müzikalde, Georges Seurat ile onun 'La Grande Jatte Adasında Bir Pazar Öğleden Sonrası' (1886) isimli resminde görünen modeli 'Dot' arasındaki ilișki konu edinmektedir. Oyunun 1984'te Off-Broadway'deki yapımında sahne tasarımı Tony Straiges, kostüm tasarımı ise Patricia Zipprodt ve Ann Hould-Ward tarafından yapılmıștır. Sondheim'ın oyun metninde Seurat'nın resminden yola çıkılarak kurgulanan dünyada ressamın düzen, tasarım, simetri, denge ve uyumu cisimleştiren bir sanat eseri yaratmak üzere dünyayı yeniden düzenleyip geliştirerek, gerçeğin çirkin karmaşasını dönüştürme süreci anlatılmaktadır. Sahne tasarımında, resim sanatını nasıl algıladığı ve icra ettiği gösterilen Seurat'nın, iki yıllık bir başyapıt üretme sürecini kurgusal düzeyde resmin içindeki figürleri canlı birer karaktere dönüştürülerek görselleştirilmektedir. Metnin bu yapısından dolayı müzikalin farklı ekiplerce her yapımında oyuncular tarafından 'La Grande Jatte Adasında Bir Pazar Öğleden Sonrası' canlı resim olarak sahneye taşınmaktadır. Performans sırasında Seurat, ön sahnede üç boyutlu oyuncular ve arka planda iki boyutlu siluetlerle resmini yapmaktadır. Seurat başyapıtını seyircilerin gözleri önünde oluştururken Straiges'in dekorları zemin boyunca firlayarak ortaya çıkar ve ön sahne 'gerçek karakterler'in mekânın arka sahne hacmini dolduran boyalı karakterlerden ayırt edilmesine olanak sağlar. Straiges, resimde perspektif duygusunu yaratmak için iki boyutlu açılır dekorları yerleştirerek perspektifi dönüştürmüştür. Sahne arkası ölçeği, ön sahnedeki oyuncularla orantılıdır. İki boyutlu açılır dekorlarla üç boyutlu oyuncuları birleștirerek tüm 'boyalı' imge düzleştirilmiştir (Benedetto, 2012, s. 172). Oyunun ışık tasarımı ise Richard Nelson tasarından yapılmıştır. Özel efekt ekibiyle, Seurat'nın stüdyosunun ve parkın üç boyutlu dekorunu ve resmin bitmiş halinin sahne büyüklüğünde replikasını yapmak için yakın işbirliği halinde çalışmıştır. Seurat'nın firça vuruşlarının dokusunu verebilmek için pin spotlarla aydınlatma kullanmıştır. Nelson, resmi körü körüne yeniden yaratmak yerine ressamın tekniğini sezdirecek bir atmosfer yaratmıştır (Benedetto, 2012, s. 176). Bu tasarım yaklaşımlarının birleşimiyle bu sahneleme örneğinde, bir resim kompozisyonunun nasıl iki boyutlu bir zeminden derinlik halde üç boyuta evrilebileceğini görmekteyiz. Oyunun odak noktası olan resmin figüratif ve kalabalık bir sahne olması ile birlikte tüm resim kalabalık oyuncu kadrosu ile tiyatro sahnesine yayılmaktadır. Aynı zamanda oyunun farklı prodüksiyonlarında döner sahne zemini de kullanılarak derinlikli olarak resmedilen kompozisyonun farklı açılardan izlenebilmesi sağlanmaktadır.

Kostüm ve makyaj tasarımlarındaki resimsel üslup etkilerini inceleyebileceğimiz örnekler arasında ise ilk olarak 2016 yılında İstanbul Devlet Tiyatrosu'nda sahnelenen 'Huzur' oyunu gösterilebilir. Kostüm ve makyaj tasarımlarını Șirin Dağtekin Yenen'in yaptı̆̆ı bu oyunda Art Nouveau ve Empresyonizm resimlerinde görülen desenler ve süslemeler kıyafetlerde dikkat çekmektedir. Özellikle Vincent Van Gogh'un ve Gustav Klimt'in resimlerinden detaylarla kostüm tasarımları şekillendirilmiştir. Oyuncuların makyaj tasarımlarında ise resimsel etkiyi destekleyecek şekilde fırça darbesi biçimleri ve çizgileri kullanılmıştır.

Rossini'nin 'Il Viaggio a Reims' (Reims'e Yolculuk) adlı eseri 2017'de Opera Australia tarafından sahnelenmiş (bkz. Şekil 11) ve yapımın sahne tasarımını Paolo Fantin, kostüm tasarımlarını Carla Teti gerçekleştirmiştir. Sahne tasarımında sanat tarihinden pek çok ünlü resmin figürleri ve ressamlar canlandırılmıştır. Bazı sahnelerde sahne çerçevesi içerisine, tekrar bir resim çerçevesi eklenerek içerisinde canlandırılan klasik resim kompozisyonu, kalabalık bir oyuncu kadrosu tarafından resmedilmiștir. Eserin sanat galerisi olarak tasarlanan sahnelerinde ise modern döneme ait eserlerden figürler, bulundukları resimlerin yanında canlı birer figür olarak vücuda getirilmiştir. Bunlar arasında, Frida Kahlo ve Van Gogh'un oto porteleri, Pablo Picasso'nun Dora Maar'ın Portresi (1937) tablosu, Rene Magritte'in Adamın Oğlu (1946) tablosu, Diego Velazquez 'in Infanta Margarita (1659) tablosu, Fernando Botero'nun Melankoli Adam (1989) tablosu ve Keith Haring'in meşhur çöp adam figürü bulunmaktadır. Gerek kalabalık bir klasik dönem resim tablosunu sahne üzerinde atmosfer, ışık ve kompozisyon olarak yeniden canlandırma ve yaratma, gerek modern resim örneklerinden figürlerin kostüm tasarımlarıyla aslına uygun biçimlendirilmesi açısından bu yapım, etkileyici bir görsellik oluşturmuştur. Aynı zamanda sanat tarihinden pek çok tablonun aynı sahne tasarımında uyumlu bir şekilde bütünleştirilebilmesi açısından başarılı bir uygulama olarak göze çarpmaktadır (Papale, 2017). 


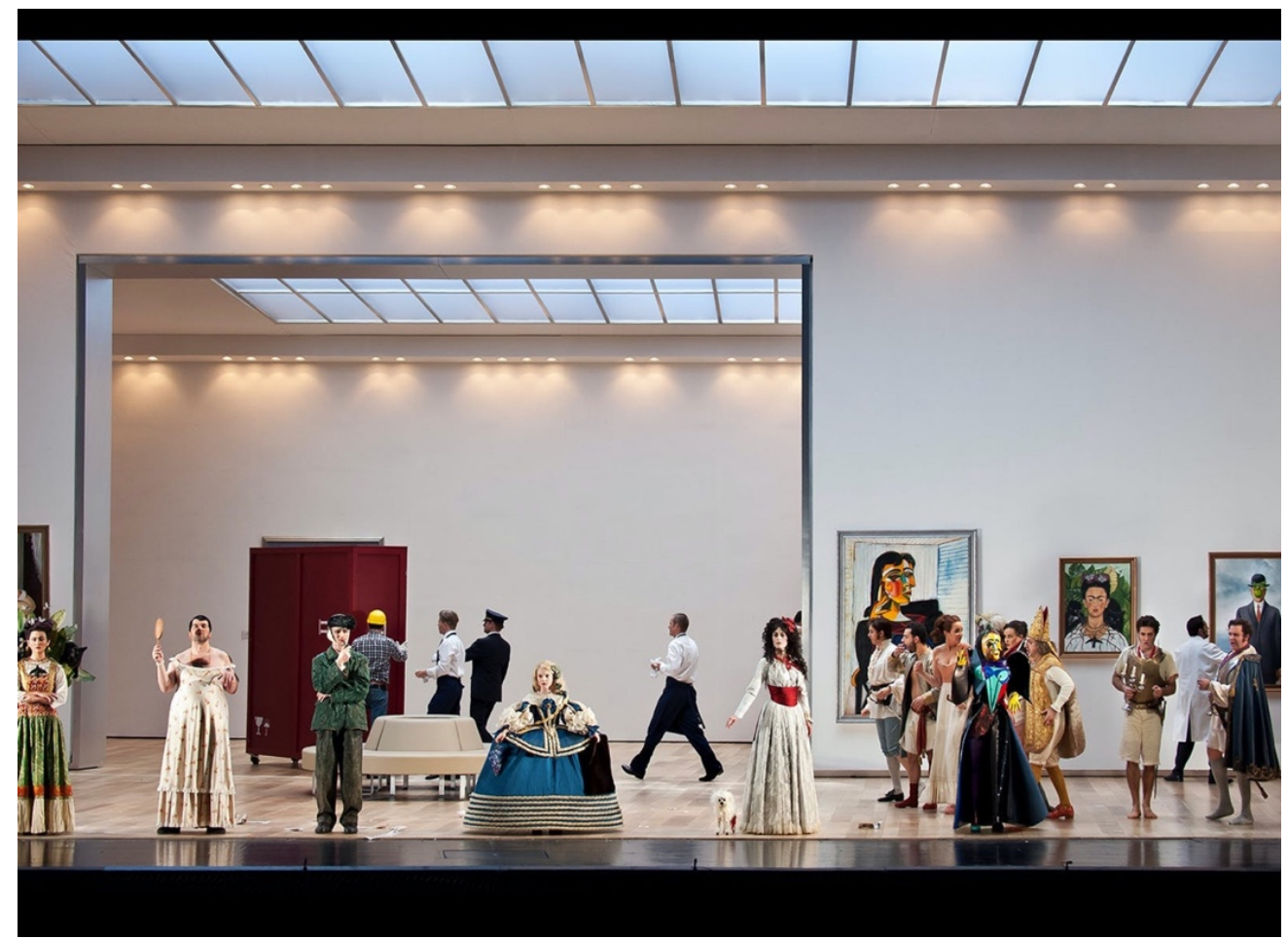

Şekil 11. Reims'e Yolculuk, Opera Australia, 2017 (Baus, 2017).

\section{Resim Üsluplarının Sahne Tasarımında Yeniden Yorumlanması}

Sahne tasarımlarındaki resimsel alıntılama tercihlerinde, dekor, kostüm ve aksesuar etmenlerinde yer alan bir modern resim figürü veya kompozisyonunun birebir görüntüsü, alıntılanan ressamla, oyun metni arasında duygusal veya düşünsel bir bağlantı arama isteği uyandırabilir. Birebir eser referansında, kullanılan görsel eserin yapıldığı dönem, eserin sanatçısı, eserin konusu, simgeleștirdiği fikir gibi birçok katmandan dramatik anlatı ile eklemlenme durumuna geçebilir. Bu durumda ele alınan resmin, bütünlüklü haliyle görsel veya düşünsel katman içinde bulunduğu sözel ve fiziksel anlatıya uyumlanmaması izleyici tarafında yanlış iletilere alınmasına sebep olabilir. Dolayısıyla sahne gösterimi içinde yer alan ve görsel tasarımın çoğunluğunu oluşturan resme fazla anlam yükü binebilir. Öte yandan sanat tarihinde çokça karşılaşılan, birçok esere göre yazılı kaynaklarda veya tasarım ürünlerinde daha çok referans gösterilmiş popüler resim örnekleri, seyirci tarafında geçmişte etkileşime geçilmiş bu eser vasıtasıyla hatırlatacağı imgeler zihinlerde değişkenlik gösterebilir. Sahne tasarımını oluşturan dekor, kostüm, aksesuar, ışıklama, makyaj gibi birden fazla katmanı hazır bir resim kompozisyonu üzerinde birleştirmenin verimli yollarından biri de sahne tasarımcısının, referans aldığı sanatçı veya eserlerin estetiğine, biçimine kendi yorumunu katarak sahne görselliğine taşımasıdır.

Resim, animasyon, baskı, performans sanatları gibi farklı disiplinlerde çalışmalarını sürdüren çok yönlü sanatçı William Kentridge'in (d.1955) sahne tasarımı çalışmalarında pek çok modern ressamın etkisi gözlemlenmektedir. Örneğin, New York Metropolitan Operası'nın 2015'de sahnelediği 'Lulu' yapımında Kentridge, sahne görselliğini oluștururken ürettiği kaligrafik çizimlerde Pablo Picasso, Henri Matisse, Emile Nolde, Max Beckmann ve Otto Dix gibi modern ressamların stilleri, figür biçimleri gözlemlenmektedir. Hem kostüm tasarımlarında hem sahne üzerine projeksiyonla yansıtılan çizimlerde bütünlüklü bir çizgi estetiği oluşturulmuş ancak tek elden çıkmış bu tasarım çizimlerinde farklı sanatçıların firçalarından resimsel alıntılar gözlemlenmektedir (Mccoy, 2016).

2013 yılında Londra Ulusal Tiyatrosu tarafindan sahnelenen 'Emile and the Detectives' yapımında ise Alman Ekspresyonizm resim estetiğiyle biçimlendirilmiş bir mekân tasviri görülmektedir. Sahne tasarımcısı Bunny Christie'nin gerçekleştirdiği sahne tasarımında, karanlık bir şehrin diyagonal çizgiler ve birbirine çarpık formlarla betimlenmesi ressam Lyonel Feininger'ın (1871-1956) resimlerini anımsatmaktadır. Feininger'ın resimlerinde çoğunlukla görülen ekspresyonist şehir tasvirleri ve bu resimlemelerdeki homojen koyu-açık renk geçişleri, sahne tasarımındaki ışıklama tercihleri ile paralellikler göstermektedir (Billington, 2013). 
Royal Shakespeare Company'nin 2016 yılında sahneye koyduğu 'Hamlet' yapımında ise, sahne tasarımcısı Paul Wills ve kostüm tasarımcısı Cathy Hill tarafından, oyunun görsel dili soyut dışavurumcu ressam Jean Michel Basquiat'nın (1960-1988) resimleri, fırça darbeleri, simgeleri referans alınarak oluşturulmuştur. (bkz. Şekil 12) Klasik bir Shakespeare eserine modern bir yorum katan bu görsel tercih ile Basquiat resimlerinde görülen șekiller, çizgiler, semboller dekor, kostüm, aksesuar tasarımlarının tümüne işlenmiştir. Sahne tasarımını oluşturan etmenlerin görselliğine bakıldığında, Basquiat'nın tasarladığı dünyada trajik bir öykü izleniyor etkisi yaratmaktadır. Ancak bu tasarım yaklaşımında ressamın tek bir resmi kaynak alınıp, sahneye uyarlanmamış, sanatçının eserlerinde görülen kendine has resim üslubu oyunun bütün yüzeylerine göre parçalanıp, yorumlanarak aktarılmıştır (Howes, 2018).

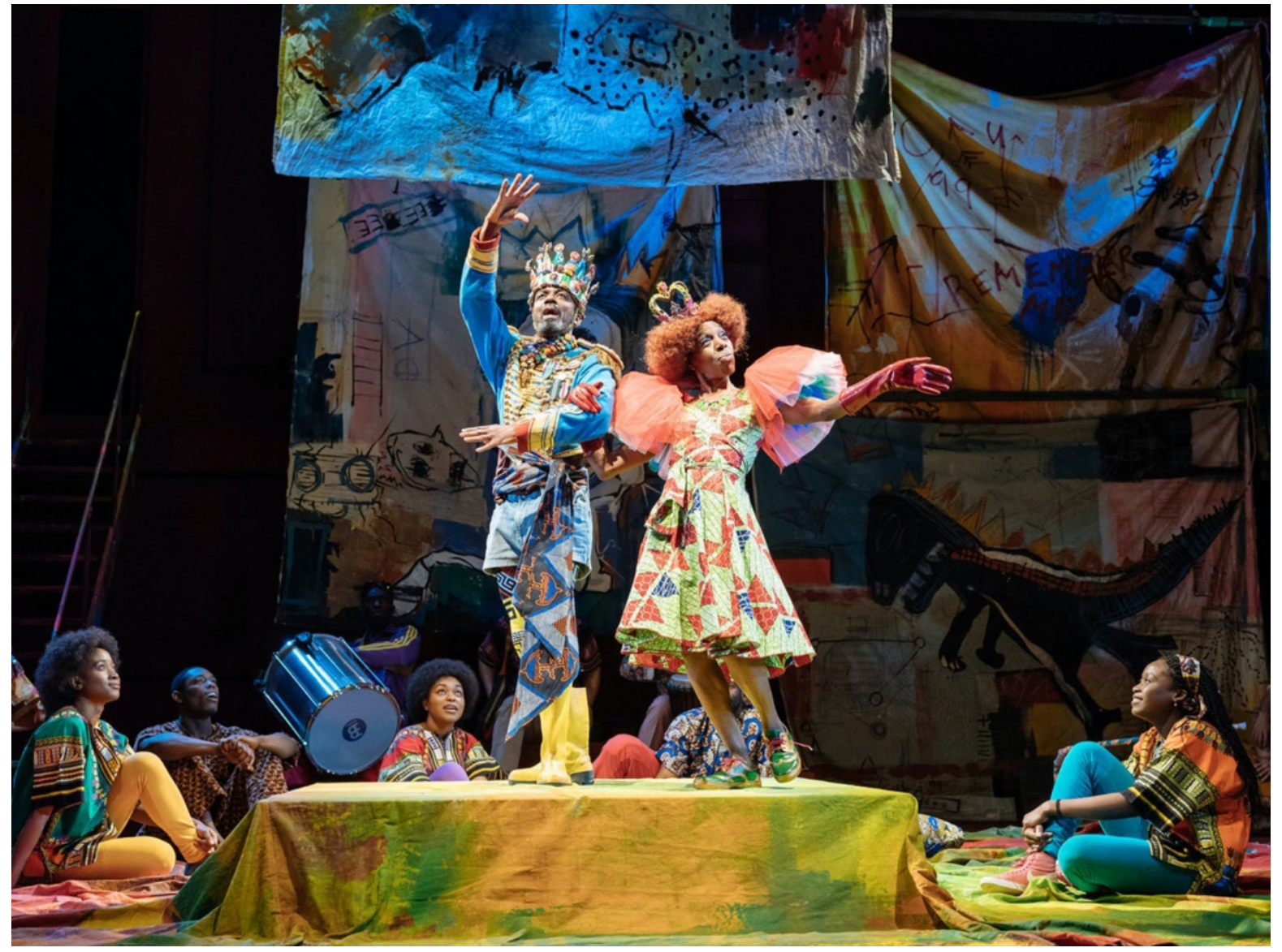

Şekil 12. Hamlet, Royal Shakespeare Company, 2016 (Harlan, 2018).

\section{Sonuç}

Tiyatronun resim sanatı ile renk kullanımından tonlamaya, ritim ve harekete ve perspektife kadar benzerlikleri vardır. Sanatın disiplinler arası özelliği, farklı disiplinlerdeki uygulayıcıların birbirlerinden etkilenmesini mümkün kılmaktadır. Bu etkileşim sanat uygulayıcıları tarafından kendi alanlarına aktarıldığında ortaya, etkileşimin sonucu olarak son derece zengin ve katmanlı bir çalışma çıkmaktadır. Resmin temel unsurlarını bilen ve bu unsurları sahne üzerinde uygulayan dekoratör, yönetmen ve oyuncular oyunun görsel ve işitsel iletilerine yeni katmanlar ekleyebilmektedir. Oyun başlayıp perde açıldığında seyircinin gördüğü ilk görüntü sahne dekorudur. Resmin unsurlarından oluşan bu görüntünün doğru düzenlenmesi, perdenin açılmasından oyunun bitimine kadar oyunun mesajının seyirciye iletilmesi bakımından yönetmenin ve sahne tasarımcısının en güçlü anlatım araçlarından ve oyuncuların en güçlü desteklerinden biridir. Nasıl ki dekor elemanları sahnede yaşamın bir görüntüsünü oluşturuyorsa, resim yüzeyinde de resmin elemanları yaşamın parçalarını oluşturur ve resim yüzeyi yaşamın görüntüsüne dönüşür. Tiyatro ve resim sanatları bu bakış açısıyla da birbirine benzemektedirler. Tiyatroda yaşamın sahnelenmesi gibi, resim yüzeyinde de formlar, çizgiler ve renklerle yaşamdan anlar oluşturulmaktadır (Nakilcioğlu, 2019, s. 30-31). 
Çalışmada ele alınan örnek sahne yapımlarında da gözlemlendiği gibi sahne tasarımlarında resim unsurları, tek tek ya da bir arada yorumlanabilmektedir. Sahne eserinin görsel kimliği ve dramatik atmosferi için seçilen resim kompozisyonu kimi zaman biçimsel deformasyonlara uğratılmadan seyircinin tanıyabileceği şekilde kullanılmış kimi zaman birkaç eserin veya sanatçının üslubundan yararlanılarak resimsel bir dünya yaratılmıştır. Tiyatro eserinde bir yorumlama biçimi olarak referans alınan resim unsurları, sahnenin reji planlaması ve hacimsel yapısı düşünülerek uygulanmaktadır. Bir sahnede boyayla birebir çalışma olmasa da yüzeyler, renkler, formlar ve derinlik vardır. Bu unsurlar, sahnede resim temeliyle düşünmek ve sahneyi resim temeliyle tasarlamak için gereklidir. Bu tarz bir tasarım yaklaşımında alıntılanan resim eserleri, sahne tasarımını oluşturan kostüm, dekor, aksesuar ve ışık uygulamalarının parçalı yapısında bütünlüklü bir görünüm ve anlatı olușturmak üzere katmanlı bir șekilde kullanılabilmektedir. Üretim așamasından temsil aşamasına geçildiğinde ise seyircinin, sahne tasarımının temelini ve görsel kimliğini oluşturan resim referansını algılayabilmesi, alıntılanan eserin veya resim üslubunun özgünlüğü ve tanınırlığına bağlıdır. Bu doğrultuda performe edilen tiyatro eserinin sahne üzerindeki görsel kimliği, iletileri, dokuları ve renkleri oluşturan resim kompozisyonu ile homojen bir şekilde içerik bağlamında uyum sağlaması dramatik anlatıya zenginlik katmaktadır.

\section{Teşekkür}

Bu makalenin kuramsal çerçevesine yaptığı katkılarından dolayı doktora tez danışmanım Prof. Dr. Selda Kulluk Yerdelen'e teşekkür ederim.

\section{Kaynakça}

Akmen, Ü. (2010, 19 Ocak). Van Gogh. Tiyatro Gerçek. https://tiyatronline.com/van-gogh_-tiyatro-gercek6877

Battista, A. (2016, 27 Nisan). Two approches to costume designs: from André Derain to Adeline André. https://www.irenebrination.com/irenebrination_notes_on_a/2016/04/andre-derain-adelineandre.html

Baus, M. (2017). Reims'e yolculuk. Opera Australia. https://features.opera.org.au/art-of-il-viaggio-areims/index.html

Beechey, G. (2015). Ideal Pyramus and Thisbe. https://www.ludwig-van.com/toronto/2015/11/09/scrutiny-pyramus-and-thisbe-repeat-afterme-less-is-not-less/

Benedetto, S. Di (2012). Tiyatro tasarımı. De Ki Yay.

Billington, M. (2013, 5 Aralık). Emil and the detectives. Review. https://www.theguardian.com/stage/2013/dec/05/emil-detectives-review

Erickson, T. C. (2016). Huntington theatre company announces 2018-19 season. https://www.americantheatre.org/2018/03/02/huntington-theatre-company-announces-201819-season/

Filippetti, J. (2011, 11 Ağustos). "André Chénier opera on the Lake at Bregenz", https://www.designboom.com/art/andre-chenier-opera-on-the-lake-at-bregenz/

Fischer-Lichte, E. (2016). Performatif estetik. Ayrıntı Yayınları.

Franceschini, L. (2009, 15 Ocak). Parma, Teatro Regio: "i lombardi alla prima crociata”, https://www.gbopera.it/2009/02/i-lombardi-aprono-la-stagione-invernale-al-regio-di-parma/

Gerçek, H. (2012). Van Gogh. Tiyatro Gerçek. http://www.tiyatrogercek.com/oyun.asp?oyn=130

Harlan, M. (2018). Hamlet. Royal Shakespeare Company. https://www.todaytix.com/x/london/shows/9251-hamlet

Hodge, P. (2012, 23 Eylül). SF opera's stunning setting of Verdi's masterpiece. Rigoletto Review. https://operanut.net/2012/09/rigoletto-review-sf-operas-stunning-setting-of-verdismasterpiece/ 
Howes, S. (2018, 5 Mayıs). 'Hamlet' by the Royal Shakespeare Company. Review. https://dcmetrotheaterarts.com/2018/05/05/review-hamlet-by-the-royal-shakespearecompany/

Kakol, C. (2019). Frida. Florida Grand Opera (2019). https://www.schmopera.com/appropriatelystrange-frida-at-fgo

Kolnik, P. (2014). New York city ballet. Symphonic Dances, Pictures at an Exhibition, This Bitter Earth, Everywhere We Go - Washington. https://dancetabs.com/2015/04/new-york-city-ballet-21stcentury-choreographers-bill-washington/

Mccoy, A. (2016, 15 Aralık). William Kentridge Takes New York. https://brooklynrail.org/2015/12/theater/william-kentridge-takes-new-york

Midgette, A. (2014, 18 Ekim). When art sings: How Paintings Have Fared on the Musical and Opera Stage. https://www.washingtonpost.com/entertainment/music/when-art-sings-how-paintings-havefared-on-the-musical-and-opera-stage/2014/10/15/e1292446-53d8-11e4-809b8cc0a295c773_story.html?utm_term=.dd1582629171

Nakilciğlu, B. (2019). Devlet tiyatrosu sahne dekorunda resim unsurları bağlamında gerçekleştirme yöntemi (1980-2010), [Yayınlanmamış yüksek lisans tezi]. Afyon Kocatepe Üniversitesi Sosyal Bilimler Enstitüsü Sanat ve Tasarım Ana Bilim Dalı.

Papale, I. (2017, 1 Temmuz). Damiano Michieletto e Stefano Montanari regalano uno strepitoso Viaggio a Reims di Rossini al Teatro dell'Opera di Roma. https://www.danzaeffebi.com/dintornidanza/damiano-michieletto-e-stefano-montanari-regalano-uno-strepitoso-viaggio-reims-dirossini-al-teatro-dellopera-di-roma/

Pisano, S (2018). Opera Philadelphia presents 'La Bohème'. https://bachtrack.com/de_DE/reviewboheme-livermore-vasquez-johnson-rovaris-opera-philadelphia-april-2019

Raley, J. (2004). Hoffmann Masalları. Marylan Opera Stüdyosu. https://www.erhardrom.com/portfolio$1 \# /$ tales-of-hoffman

Ricci, R. (2009). I Lombardi alla Prima Crociata - Teatro Regio di Parma. http://www.liricamente.it/showdocument.asp?iddocumento $=250$

Sachs, V. (2019). Left Coast Chamber Ensemble 2019 Review: 'Dorothea and Artemesia'. https://operawire.com/left-coast-chamber-ensemble-2019-review-dorothea-and-artemesia/

Sekoff, H. (201, 6 Aralık). 'La Boheme' At Philadelphia Opera Uses High-Tech Van Goghs and Renoirs, https://www.huffpost.com/entry/opera-company-of-philadelphia_n_1912294

Sullivan, L. (2016, 28 Mart). Finzi Pasca contemporary circus to perform 'La Verità' April 21 at Eisenhower, https://news.psu.edu/story/399962/2016/03/28/arts-and-entertainment/finzipasca-contemporary-circus-perform-\%E2\%80\%98la-verit\%C3\%A0\%E2\%80\%99

Ünlü, A. (2015). Biyografi ve biyografik dram. NoteBene Yay.

Vallejo, A. B. (2000). Goya, ya sanat ya ölüm(H. Tukur, Çev.) Can Yayınları.

Vincent, M. (2015, 9 Kasım). Pyramus and Thisbe: Repeat after Me, Less is Not Less, https://www.ludwigvan.com/toronto/2015/11/09/scrutiny-pyramus-and-thisbe-repeat-after-me-less-is-not-less/

Weaver, C. (2017). San Francisco Opera Opens 90th Season with Verdi's 'Rigoletto'. http://www.classicalvoice.org/review/san-francisco/2017/6/10/san-francisco-opera-kicks-offsummer-season-with-rigoletto 